\title{
Effects of miniaturization in the anatomy of the minute springtail Mesaphorura sylvatica (Hexapoda: Collembola: Tullbergiidae)
}

\author{
Irina V. Panina ${ }^{\text {Corresp., } 1}$, Mikhail B. Potapov ${ }^{2}$, Alexey A. Polilov ${ }^{\text {Corresp. } 1}$ \\ 1 Department of Entomology, Faculty of Biology, Moscow State University, Moscow, Russia \\ Department of Zoology and Ecology, Institute of Biology and Chemistry, Moscow State Pedagogical University, Moscow, Russia \\ Corresponding Authors: Irina V. Panina, Alexey A. Polilov \\ Email address: i.vl.panina@gmail.com, polilov@mail.bio.msu.ru
}

Smaller animals display pecular characteristics related to their small body size, and miniaturization has recently been intensely studied in insects, but not in other arthropods. Collembola, or springtails, are abundant soil microarthropods and form one of the four basal groups of hexapods. Many of them are notably smaller than $1 \mathrm{~mm}$ long, which makes them a good model for studying miniaturization effects in arthropods. In this study we analyze for the first time the anatomy of the minute springtail Mesaphorura sylvatica (body length $400 \mu \mathrm{m}$ ). It is described using light and scanning electron microscopy and 3D computer reconstruction. Possible effects of miniaturization are revealed based on a comparative analysis of data from this study and from studies on the anatomy of larger collembolans. Despite the extremely small size of $M$. sylvatica, some organ systems, e.g., muscular and digestive, remain complex. On the other hand, the nervous system displays considerable changes. The brain has two pairs of apertures with three pairs of muscles running through them, and all ganglia are shifted posteriad by one segment. The relative volumes of the skeleton, brain, and musculature are smaller than those of most microinsects, while the relative volumes of other systems are greater than or the same as in most microinsects.

Comparison of the effects of miniaturization in collembolans with those of insects has shown that most of the miniaturization-related features of $M$. sylvatica have also been found in microinsects (shift of the brain into the prothorax, absent heart, absence of midgut musculature, etc.), but also has revealed unique features (brain with two apertures and three pairs of muscles going through them), which have not been described before. 
1 Effects of miniaturization in the anatomy of the minute springtail Mesaphorura sylvatica

2 (Hexapoda: Collembola: Tullbergiidae)

3

4 Irina V. Panina ${ }^{1}$, Mikhail B. Potapov², Alexey A. Polilov ${ }^{1}$

$5{ }^{1}$ Department of Entomology, Faculty of Biology, Moscow State University, Moscow, Russia

6 2Department of Zoology and Ecology, Institute of Biology and Chemistry, Moscow State

7 Pedagogical University, Moscow, Russia

Corresponding Authors:

Irina V. Panina

Email address: i.vl.panina@gmail.com

14 Alexey A. Polilov

15 Email address: polilov@gmail.com 


\begin{abstract}
Smaller animals display peculiar characteristics related to their small body size, and miniaturization has recently been intensely studied in insects, but not in other arthropods. Collembola, or springtails, are abundant soil microarthropods and form one of the four basal groups of hexapods. Many of them are notably smaller than $1 \mathrm{~mm}$ long, which makes them a good model for studying miniaturization effects in arthropods. In this study we analyze for the first time the anatomy of the minute springtail Mesaphorura sylvatica (body length $400 \mu \mathrm{m}$ ). It is described using light and scanning electron microscopy and 3D computer reconstruction. Possible effects of miniaturization are revealed based on a comparative analysis of data from this study and from studies on the anatomy of larger collembolans.

Despite the extremely small size of M. sylvatica, some organ systems, e.g., muscular and digestive, remain complex. On the other hand, the nervous system displays considerable changes. The brain has two pairs of apertures with three pairs of muscles running through them, and all ganglia are shifted posteriad by one segment. The relative volumes of the skeleton, brain, and musculature are smaller than those of most microinsects, while the relative volumes of other systems are greater than or the same as in most microinsects.

Comparison of the effects of miniaturization in collembolans with those of insects has shown that most of the miniaturization-related features of $M$. sylvatica have also been found in microinsects (shift of the brain into the prothorax, absence of heart, absence of midgut musculature, etc.), but has also revealed unique features (brain with two apertures and three pairs of muscles going through them), which have not been described before.

Keywords: miniaturization, morphology, anatomy, Collembola, body size
\end{abstract}

\title{
INTRODUCTION
}

Miniaturization plays an important role in morphological changes in animals and has become a popular area of research (e.g. Hanken \& Wake, 1993; Polilov, 2016a). Many arthropods are comparable in size with unicellular organisms and are of great interest for studying miniaturization in animals. Miniaturization implies major morphological changes of structures and is often accompanied by allometric changes in many organs (Polilov, 2015a). The tremendous size changes that occurred in the evolutionary history of arthropods may have allowed them to occupy a vast range of niches. Studies on miniaturization in different arthropods can help us understand what limits body size in organisms and how miniaturized organisms evolved.

Morphological traits (rev.: Polilov, 2015a; Polilov, 2016a; Minelli \& Fusco, 2019), scaling of organs (Polilov \& Makarova, 2017), and even cognitive abilities (van der Woude et al., 2018; Polilov et al., 2019) associated with miniaturization have been studied in insects. Studies on other minute Panarthropoda are scarce (Eberhard \& Wcislo, 2011; Dunlop, 2019; Gross et al., 2019).

Studies on the miniaturization of insects and the anatomy of the smallest insects (adult body length smaller than $2 \mathrm{~mm}$ ) show significant changes in the anatomy of microinsects correlated with their size. Some changes are commonly shared by remotely related taxa, and seem to be straightforward adaptions to physical constrains, e.g., the reduction of circulatory and tracheal systems, absence of midgut musculature; compactization, oligomerization, and asymmetry of central nervous system (Polilov, 2016a). However, some microinsect taxa possess their own original modifications, such as the complete shift of the brain into the thorax in the adult (Polilov 
62

63

64

65

66

67

68

69

70

71

72

73

74

75

76

77

78

79

80

81

82

83

84

85

86

87

88

89

90

91

92

93

94

95

96

97

98

99

100

101

102

103

104

105

106

107

\& Beutel, 2010) in the beetle Mikado sp., or the lysis of cell bodies and nuclei of neurons in the parasitic wasp Megaphragma sp. (Polilov, 2012, 2017).

Size range of Collembola is from 0.12 to $17 \mathrm{~mm}$. Factors such as soil interstices space and humidity levels affect size reduction of collemblans. Thus, many collembolan genera include especially minute species $(<500 \mu \mathrm{m})$, and therefore represent interesting models for research on miniaturization in arthropods. However, studies on the effects of miniaturization in collembolans have not been performed yet, and data on the anatomy of minute collembolans are extremely scarce. Previous studies on collembolan anatomy were based mostly on larger species (Table S1). Moreover, the majority of them were concentrated on specific systems only. Lubbock (1873) described the anatomy of several species, but studied only the largest muscles of the body, and the head musculature was not mentioned. Fernald (1890) described the anatomy of Anurida maritima, but he studied only the muscles associated with the digestive system, and the excretory system was not mentioned in his study. Willem (1900) briefly described the anatomy of 12 species, but the muscular and excretory systems were not mentioned. Prowazek (1900) described the embryology and anatomy of both larvae and adults of Isotoma grisea and Achorutes viaticus, but the head musculature was not mentioned. Denis (1928) described the anatomy of $A$. maritima, Onychiurus fimetarius, and Tomocerus catalanus, but the reproductive system and musculature of the body (except the head musculature) were not mentioned. Mukerji (1932) described the digestive, nervous, and excretory systems, and partly the head musculature of Protanura carpenteri. In addition, there were several studies on the muscular system of Orchesella cincta (Folsom, 1899; Bretfeld, 1963), Neanura muscorum (Bretfeld, 1963), Tomocerus longicornis (Lubbock, 1873), Tomocerus spp. (Eisenbeis \& Wichard, 1975), Orchesella villosa, Isotomurus palustris, Podura aquatica, and Sminthurus viridis (Imms, 1939), the digestive system of Tomocerus flavescens (Humbert, 1979), the digestive and excretory systems of O. cincta (Verhoef et al., 1979), T. flavescens, A. maritima, N. muscorum, Friesea mirabilis, Brachystomella parvula, Odontella armata (Wolter, 1963), and Sminthurus fuscus (Willem \& Sabbe, 1897), the excretory system of Onychiurus quadriocellatus (Altner, 1968), Tomocerus minor, Lepidocyrtus curvicollis (Humbert, 1975), and Orchesella rufescens (Philiptschenko, 1907), the respiratory system of S. viridis (Davies, 1927), the nervous system of Folsomia candida, Protaphorura armata, and Tetrodontophora bielanensis (Kollmann et al., 2011), the reproductive system of Allacma fusca (Dallai et al., 2000), O. villosa (Dallai et al., 2008), A. maritima (Lécaillon, 1902a), and Anurophorus laricis (Lécaillon, 1902b). Schaller (1970) and Hopkin (1997) gave partial reviews of the above in their synthetic books on Collembola.

The genus Mesaphorura includes some of the smallest species of Collembola, the adults some of them are only $0.4 \mathrm{~mm}$ long (Zimdars and Dunger, 1994). The external morphology of Mesaphorura has been completely and thoroughly investigated for systematic and phylogenetic purposes (Zimdars \& Dunger, 1994; D’Haese, 2003), but its internal morphology has never been described. The aim of this work is to study the anatomy of Mesaphorura sylvatica for the first time and to describe the effects of miniaturization in this species.

\section{MATERIALS AND METHODS}

This complex anatomical study was conducted based on the methods for the study of microinsects described in previous papers (Polilov, 2016a, 2017; Polilov \& Makarova, 2017).

\section{Materials}


108

Specimens of Mesaphorura sylvatica Rusek, 1971 were collected in September 2015 on a sand beach, on the bank of the Pirogovskoye Reservoir, Moscow Oblast, Russia, using the flotation method. The material was fixed in alcoholic Bouin's solution and stored in 70\% ethanol.

\section{Scanning electron microscopy (SEM)}

External morphology was studied using a Jeol JSM-6380 scanning electron microscope following critical point drying (Hitachi HCP-2) and sputter coating of samples with gold (Giko IB-3).

\section{Histology}

The fixed material was dehydrated in a series of increasing ethanol solutions (in $70 \%$ and $95 \%$ for an hour, and twice in 100\% for $30 \mathrm{~min}$ ) and in acetone (twice in 100\% for $30 \mathrm{~min}$ ), and afterwards embedded in Araldite M (kept in a mixture of araldite and acetone 1:1 for a night, then twice in araldite for four hours, following polymerization at $60^{\circ} \mathrm{C}$ for two days). The blocks were cut into series of cross sections $1 \mu \mathrm{m}$ thick and longitudinal sections $0.5 \mu \mathrm{m}$ thick using a Leica RM2255 microtome. These sections were stained with toluidine blue and pyronine.

\section{Three dimensional computer reconstruction (3D)}

The sections were photographed using a Motic BA410 microscope with LED illumination source and ToupTek camera (5 MP). The resulting stack was then aligned and calibrated. 3D reconstructions were created in the program Bitplane Imaris 7.2 using the function of creating vector surface manually by outlining contours of structures on a series of slides. In addition, we processed the reconstructions with the functions of surface smoothing and rendering in the Autodesk Maya 2015 program.

\section{Measurements}

The body length was measured using SEM images. Linear measurements were based on images of histological slides in the program Bitplane Imaris. Volumes of organs (Table S2) and of the whole body were calculated using the statistical module of Bitplane Imaris, as described in an earlier study (Polilov \& Makarova, 2017). For all measurements we calculated means, n-number, and minimum and maximum values, where it was possible with a given sample size.

\section{Nomenclature}

The names of morphological elements are based on Folsom (1899), Snodgrass (1935), Bretfeld (1963), and Bitsch (2012). The description of the musculature and abbreviations of muscles (Table S3) are based on Folsom (1899) for the head, Bretfeld (1963) for the thorax and abdomen, and Eisenbeis and Wichard (1975) for the ventral tube, with some additions. Muscles are named according to the nomenclature used for insects (Friedrich \& Beutel, 2008; Wipfler et al., 2011). The following abbreviations are used in descriptions of muscles: O, origin; I, insertion.

\section{RESULTS}

\section{General morphology}

The body is from 313 to $492 \mu \mathrm{m}(\mathrm{M}=425, \mathrm{n}=4)$ in length (Fig. 1A-C), uniformly white in color. Jumping organ (furca), tenaculum and eyes are absent. It is important to note that the name "furca" is also applied to endoskeletal structures in thorax of hexapods ("furca-like structures" mentioned below). Most of the head is occupied by the brain, the suboesophageal ganglion, the 
154

155

156

157

158

159

160

161

162

163

164

165

166

167

168

169

170

171

172

173

174

175

176

177

178

179

180

181

182

183

184

185

186

187

188

189

190

191

192

193

194

195

196

197

198

199

mouthparts and the complex pseudotentorium; the prothorax is occupied by part of the suboesophageal ganglion, while the meso- and metathorax are occupied by the wide midgut and fat body; the abdomen is mainly occupied by the reproductive system, with the digestive system above it (Fig. 2A-D, Fig. S1). All tagmata have well-developed musculature.

The body volume of M. sylvatica is about $0.79 \mathrm{nl}$.

\section{Skeleton}

The cuticle thickness is $0.31-1.24 \mu \mathrm{m}(\mathrm{M}=0.57, \mathrm{n}=80)$. The tergites are well-developed; the sclerites and pleurites are hardly distinguishable.

The inner skeletal structures are highly developed. A complex pseudotentorium (pst) (Fig. 3A-B, D-F) is situated in the head. Its body (bp) consists of a mandibular tendon in the middle, which continues posteriorly into a thinner longitudinal endoskeletal connective. There is a pair of dorsal suspensory arms (dsa), connecting the structure with the head capsule anteriorly on the frons. The glossa is prolonged posteriorly into a pair of chitinous stalks (ful), called the posterior tentorial apodemes by Koch (2000), or fulcra (Denis, 1928). They lie externally to the midline. The enlarged base of the stalk is called the foot (fo), and the foot underlies the cardo (car) of the maxilla (Mx). They seem to connect with the head capsule posteriorly possibly with some endoskeletal connectives. A pair of connecting arms (ca) (bras d'union, Denis, 1928) extend from the pseudotentorial plate downwards and are fused with the posterior tentorial apodemes. A pair of lateral arms (la) (bras latéraux, Denis, 1928) extend from the anterior part of the pseudotentorial plate, go upward and outward and are inserted into the head.

In Orchesella cincta, according to Folsom (1899), there is also a chitinous rod, which is attached to the base of the lobe of the lacinia. The chitinous rod has a chitinous expansion (ce), which is the attachment site for several maxillary muscles. It is shown in our model as a part of the maxilla.

Antecostae are submarginal ridges near the anterior edges of the inner surface of the tergum with several body muscles attached to them.

Three ventral furca-like structures are branched and found in the thorax between the first and the second thoracic segments, between the second and the third thoracic segments, and between the third thoracic segment and the first abdominal segment (Fig. 2C). Additionally, there is a simple rectangular endosternite in the first abdominal segment.

The volume of the skeleton is about $0.048 \mathrm{nl}(5.8 \%$ of the body volume).

\section{Digestive and excretory systems}

The alimentary canal (Fig. 4A-B) is shaped as a straight tube without loops or diverticula, extending from the anterior and ventral area of the head into the terminal abdominal segment. It is divided into fore-, mid-, and hindgut.

The slender foregut is circular in cross section and extends posteriorly from the oral cavity. It is divided into the pharynx and oesophagus (oes). The slender pharynx is about $4.2 \mu \mathrm{m}$ in diameter $(\mathrm{M}=4.2, \mathrm{n}=8)$. The oesophagus passes through the suboesophageal ganglion and leads into the thicker midgut (mg) at the level of the metathorax (around the fourth abdominal segment). The midgut consists of one layer of cells (6-8 cells in cross section). The oesophagus has one pair of muscles $1(\mathrm{Oe})$ (Fig. 3E, F). The first half of the midgut is circular in cross section, about 21.8 $\mu \mathrm{m}(\mathrm{M}=24.3, \mathrm{n}=8)$ in diameter. The second half is oval in cross section. The border between the midgut and the hindgut is indistinguishable. At around the sixth abdominal segment, the hindgut extends into the wider rectum (rt) with four pairs of muscles. The latter continues 
200

201

202

203

204

205

206

207

208

209

210

211

212

213

214

215

216

217

218

219

220

221

222

223

224

225

226

227

228

229

230

231

232

233

234

235

236

237

238

239

240

241

242

243

244

245

posteriad and terminates ventrally at the anus with three anal lobes in the last abdominal segment.

Labial nephridia (laneph), or tubular glands, the main excretory organs of collembolans, are found in the posterior half of the head (Fig. 4A-B). Each nephridium is composed of a sac, a labyrinth, and a duct. The sac is situated posteriorly and continues anteriad into the labyrinth. The labyrinth follows a hardly distinguishable winding course and forms a loop. The labyrinth continues as the duct, which opens in the buccal cavity. Other head glands (anterior and posterior salivary glands, globular, or acinous glands, and antennal nephridia) were not found in $M$. sylvatica.

The volume of the digestive and excretory systems is about $0.68 \mathrm{nl}(8.6 \%$ of the body volume).

\section{Nervous system}

The nervous system (Fig. 4C-D) consists of a supraoesophageal ganglion, or brain (cer), suboesophageal ganglion (soeg), and three thoracic ganglia. The brain extends from the bases of the antennae to the anterior part of the first thoracic segment. The brain fills the dorsal portion of the head, but narrows in the posterior portion of the head (beyond the beginning of the suboesophageal ganglion) and extends beyond the boundary between the head and the first thoracic segment. It terminates in the anterior half of the latter. The brain has a unique structure, with two pairs of apertures with one pair of oesophageal $1(\mathrm{Oe})$ and two pairs of pseudotentorial suspensory muscles 1 (Pst), 2(Pst) running through them (Fig. 3E-F). The suboesophageal ganglion (Fig. 3E; Fig 4C) lies in the ventral portion of the head, starting at its middle, and continues to the distal margin of the first thoracic segment. Three large ventral thoracic ganglia shift their position by one segment: the first ganglion (gg1) lies in the mesothorax, the second one (gg2) is in the metathorax, and the third one (gg3) is in the first abdominal segment. They are interconnected by longitudinal cords in intersegments (one in each). As in all collembolans, the abdominal ganglia (ag) are fused with the third thoracic ganglion.

The volume of the central nervous system is about $0.051 \mathrm{nl}(6.3 \%$ of body volume $)$. The volume of the brain is about $0.016 \mathrm{nl}$ (2.2\% of the body volume).

\section{Muscular system}

Musculature of head (Fig. 3B-F, Table 1). M. sylvatica has 24 pairs of muscles in the head. Two of them are connected to the pseudotentorium, one to the antennae, nine to the mandibles, six to the maxillae, one to the oesophagus, and two of them are the dorsal lateral pairs of muscles. In addition, there are three very small obscure muscles that are connected to the hypopharynx. Two mandibular muscles $8(\mathrm{Mn})$ cross each other and attach to the opposite sides of the head.

Musculature of thorax (Fig. 5A-C, Table 2).

Prothorax. M. sylvatica has 14 pairs of muscles in the prothorax. Two of them are dorsal longitudinal, one ventral longitudinal, two intersegmental dorsoventral, five dorsoventral, and four sterno-coxal.

Mesothorax. M. sylvatica has 19 pairs of muscles in the mesothorax. Compared to the prothorax, it has more dorsoventral (eight) and sterno-coxal (six) pairs of muscles. Metathorax. M. sylvatica has 18 pairs of muscles in the mesothorax. Compared to the mesothorax, only one pair of muscles (III scm4) is absent.

Musculature of abdomen (Fig. 6A-B, Table 3). M. sylvatica has 61 pairs of muscles and one unpaired muscle in the abdomen. Ten pairs of muscles are dorsal longitudinal, three ventral 
246 longitudinal, eight intersegmental dorsoventral, 29 dorsoventral. In addition, there are 11 pairs of

muscles that are connected to the ventral tube. One unpaired transversal muscle connects abdominal endosternites of both sides.

The volume of the muscular system is about $0.038 \mathrm{nl}(5.2 \%$ of the body volume).

\section{Reproductive system}

The female reproductive system has been studied in detail (Fig. 4E-F). The ovary is unpaired with three lobes. The largest lobe (eg) probably contains eggs, while two other, smaller lobes (ova) contain no eggs and lie dorsad of the largest one. The anterior portion of the ovary lies between the abdominal segments 2 and 3, while its posterior portion ends between abdominal segments 4 and 5. The oviduct is small, short and unpaired, leading to the vagina (va), the margins of which are indistinct. The vagina opens ventrally on abdominal segment 5 with a transverse reproductive orifice (gonopore).

The volume of the reproductive system is about $0.15 \mathrm{nl}(18.9 \%$ of the body volume).

\section{Circulatory system and fat body}

Organs of the circulatory system are absent, the system is represented by hemolymph in the body cavity. The fat body occupies all cavities between organs in the head, thorax, and abdomen. It consists of cells of various shape.

The volume of the circulatory system and fat body is about $0.44 \mathrm{nl}(55.2 \%$ of the body volume).

\section{Respiratory system \\ Organs of the respiratory system (tracheae) are absent.}

\section{DISCUSSION}

We studied the anatomy of M. sylvatica to extend the knowledge on the anatomy of Collembola as well as to reveal possible miniaturization traits and to compare them to the miniaturization effects discovered in microinsects and other minute arthropods. Moreover, we analyzed the relative volume of organs in Mesaphorura sylvatica in comparison with microinsects.

\section{Skeleton}

The endoskeletal structures of M. sylvatica are well-developed as in larger species (Manton, 1964). The complex pseudotentorium has multiple arms, and the furca-like structures are branched. However, reductions seem to have affected the abdomen, in which we observed only one endosternite, in contrast to Neanura muscorum, in which five endosternites were found (Bretfeld, 1963). In microinsects, elements of the endoskeleton tend to fuse (Polilov, 2015a; Polilov, 2015b). Of all adult microinsects, only booklice have a complex tentorium (Polilov, 2016b), and all furcae are developed in thrips, beetles of the family Corylophidae, and wasps of the family Mymaridae (Polilov and Beutel, 2010, Polilov and Shmakov, 2016, Polilov, 2016c). The relative volume of the skeleton of $M$. sylvatica is similar to the one of adult Paraneoptera of the same size, but notably smaller than the ones of other microinsects (both larvae and adults) of the same size (Polilov \& Makarova, 2017). The smaller relative volume of the skeleton of $M$. sylvatica, compared to most microinsects, could be related to the differences in cuticle thickness (due to the fragmented epicuticle of all collembolans) and to the flightlessness of collembolans.

\section{Nervous system}


292 Unlike those of larger species of Collembola (Lubbock, 1873; Kollmann et al., 2011), the brain

293

294

295

296

297

298

299

300

301

302

303

304

305

306

307

308

309

310

311

312

313

314

315

316

317

318

319

320

321

322

323

324

325

326

327

328

329

330

331

332

333

334

335

336

337 and suboesophageal ganglion of $M$. sylvatica extend into the prothorax. The three thoracic ganglia of $M$. sylvatica shift their position by one segment posteriorly. In larger collembolan species, an extension of the metathoracic ganglion to the first abdominal segment was reported (Lubbock, 1873; Hopkin, 1997). The brain and the suboesophagal ganglion are situated close to each other; they are connected in the neck region. The central nervous system is symmetrical and displays moderate concentration and oligomerization of ganglia. Similar degrees of concentration and oligomerization of the central nervous system are found in adult booklice of the family Liposcelididae (Polilov, 2016b) and in adult thrips (Polilov \& Shmakov, 2016). The shift of different parts of the brain into the prothorax has been described in thrips larvae (Polilov \& Shmakov, 2016), adults and larvae of Ptiliidae (Polilov \& Beutel, 2009), adults and larvae of Corylophidae (Polilov \& Beutel, 2010), larvae of Scydmaenidae (Jałoszyński et al., 2012), larvae of Hydroscaphidae (Beutel \& Haas, 1998), adults of Sphaeriusidae (Yavorskaya et al., 2018), and larvae of Strepsiptera (Beutel et. al., 2005).

The nervous system of M. sylvatica shows unique changes in the brain with two pairs of apertures and three pairs of muscles running through them. This feature has not been described in studies of the nervous system of larger collembolans (Lubbock, 1873; Hopkin, 1997; Kollmann et al., 2011) or microinsects (Polilov, 2015a; Polilov, 2015b).

The relative volume of the central nervous system of $M$. sylvatica is similar to the one of tiny adult Coleoptera, smaller than those of minute adult Hymenoptera and Paraneoptera larvae, and greater than those of adult Paraneoptera of the same size (Polilov \& Makarova, 2017). Such small relative volume can be explained by the tendency of the nervous system of microinsects to increase as the body size decreases (Polilov \& Makarova, 2017). It is also supported by the fact that representatives of adult minute Paraneoptera have greater body size, but smaller relative volume of the central nervous system. The smaller relative volume of the central nervous system of M. sylvatica compared to the ones of minute adult Hymenoptera and Paraneoptera larvae could be related to better pronounced effects of miniaturization in adult Hymenoptera and Paraneoptera larvae of the same size.

The relative volume of the brain of $M$. sylvatica is similar to the one of adult Coleoptera of the same size, slightly greater than the one of minute adult Paraneoptera, and notably smaller than the ones of other microinsects of the same size (Polilov \& Makarova, 2017). The smaller relative volume than in most microinsects of the same size could possibly be related to the absence of flight organs and eyes (Jordana et al., 2000).

\section{Circulatory system and fat body}

The circulatory system of M. sylvatica is simplified, heart or vessels are absent. Most of the body cavities of $M$. sylvatica are filled with the fat body. In larger collembolan species, there is a heart with 2-6 pairs of ostia and an aorta (Fernald, 1890; Denis, 1928; Imms, 1957; Schaller, 1970). The same reduction as in M. sylvatica was observed in adults and larvae of beetles of the family Ptiliidae (Polilov, 2005; Polilov \& Beutel, 2009), larvae of booklice of the family Liposcelididae (Polilov, 2016b), adult hymenopterans of the family Trichogrammatidae (Polilov, 2016d; Polilov, 2017), tardigrades (Gross et al., 2019), and some chelicerates (Dunlop, 2019). In microinsects, it is assumed that the diffusion of metabolites is sufficient enough for the transport between the organs (Polilov, 2008; Polilov \& Beutel, 2009), which is, apparently, also the case of M. sylvatica.

The relative volume of the circulatory system and fat body of $M$. sylvatica is particularly great, 
greater than the ones of other microinsects of the same size except Paraneoptera and Coleoptera larvae (Polilov \& Makarova, 2017). The high relative volume could be related to the importance of the fat body in excretion in Collembola, where excretory products are stored (Schaller, 1970).

\section{Female reproductive system}

The female reproductive system of $M$. sylvatica consists of unpaired ovaries and oviducts. In larger species, it consists of paired ovaries, oviducts and accessory glands, and an unpaired spermatheca. We did not observe accessory glands and spermatheca in $M$. sylvatica, which may be explained by the fact that they are hardly recognizable even in larger species (Schaller, 1970; Dallai, 2008). The same changes were observed in beetles of the family Ptiliidae, in which both sexes have unpaired structures (Polilov \& Beutel, 2009).

The relative volume of the reproductive system of $M$. sylvatica is also particularly great; it is smaller only than the ones of some minute adult Coleoptera and minute Hymenoptera (Polilov \& Makarova, 2017). The greater relative volume compared to those of most microinsects of the same size could be related to the relative egg size increase with decreasing body size (Polilov, 2016a).

\section{Digestive and excretory systems}

The digestive system of M. sylvatica is least modified, compared to larger species (Lubbock, 1873; Folsom, 1899; Wolter, 1963; Schaller, 1970). It is straight, without loops or diverticula. Among microinsects, only larvae of booklice of the family Liposcelididae have no loops or pronounced bends (Polilov, 2016b). No salivary glands are found in M. sylvatica. Salivary glands in some microinsects are absent as a result of miniaturization (Polilov, 2015a; Polilov, 2015b). We did not observe any muscles of the midgut, an absence of which is also a common trait among minute insects (Polilov, 2016a).

M. sylvatica has a pair of labial nephridia, but lacks other head glands (acinous glands and antennal nephridia) that are present in larger collembolan species (Wolter, 1963). In microinsects, Malpighian tubes do not disappear, but their number decreases (Polilov, 2015a). The relative volume of the digestive and excretory systems of $M$. sylvatica is similar to those of most minute Coleoptera, notably smaller than those of minute Paraneoptera, but greater than the ones of Hymenoptera and some Coleoptera species of the same size (Polilov \& Makarova, 2017).

\section{Musculature}

The muscular system of M. sylvatica is reduced in number, compared to those of larger collembolan species. M. sylvatica has 24 pairs of muscles in the head, 51 in the thorax, and 61 in the abdomen (and 1 unpaired muscle); 136 pairs in total. The total number of muscles of all tagmata have not been studied in any single species of springtails, which limits the possible comparison of our results with previous studies.

It is difficult to compare head muscles in Collembola. Folsom (1899) described at least 47 pairs of muscles in the head of a large collembolan Orchesella cincta associated with the digestive system and mouthparts. There are 26 pairs of muscles associated with mouthparts (labrum, labium, maxilla, mandible). In addition, he noted 20 pairs of muscles associated with both pharynx and oesophagus (seven of them are the ventral dilators of the pharynx, which he later classified as tentorial muscles), but he did not designate them. He mentioned the presence of tentorial muscles (dilators of pharynx, antennal, and muscles connected to the head), but did not 
384

385

386

387

388

389

390

391

392

393

394

395

396

397

398

399

400

401

402

403

404

405

406

407

408

409

410

411

412

413

414

415

416

417

418

419

420

421

422

423

424

425

426

427

428

429

specify their number. Folsom (1899) also mentioned two muscles of the palpi, but it is not clear whether he meant two pairs of muscles or two muscles in total. Denis (1928) described at least 73 pairs of muscles in the head of a large collembolan Anurida maritima associated with mouthparts, pseudotentorium and the digestive system. He divided the muscles of the head into several groups, but he specified the number of muscles only for some of them. For the mouthparts (maxilla and mandible), he remarked that for some muscles he drew a single bundle that included several muscles, but he did not specify their number. There are at least 17 pairs of muscles associated with the maxilla and mandible in A. maritima. Moreover, he described all tentorial muscles, and there are at least 45 of them (14 of those are the ventral dilators of pharynx). In addition, he mentioned superlingual muscles (the number was not given), suspensors of the atrium ( 3 pairs), 8 pairs of antennal muscles (excluding the muscles inside the antenna), and 5 muscles associated with the epipharynx and pharynx. He did not specify the number of muscles of the labium. Moreover, he described the groups of muscles of the heads of two larger species Onychiurus fimetarius and Tomocerus catalanus, but he compared them to $A$. maritima, without providing details on exact numbers. With $T$. catalanus he referred to the study of Hoffmann (1908), who described at least 53 pairs of muscles in the head of another large collembolan Tomocerus plumbeus. There are 35 muscles associated with mouthparts (maxilla, mandible, and labium), 15with the pharynx, and 3with the glossa. Hoffmann (1908) also mentioned the presence of tentorial muscles, but did not specify their number. In M. sylvatica, there are 15 pairs of muscles associated with maxilla and mandible, one pair of antennal muscles, one pair of oesophageal muscles, two pairs of suspensory pseudotentorial muscles, and three pairs of muscles, possibly associated with the hypopharynx. Moreover, there are two pairs of dorsal longitudinal muscles, while this group of muscles was mentioned, but not described in the literature. In this study, we have not described any other tentorial muscles, except those mentioned above, and internal antennal muscles due to their small size. M. sylvatica has 15 pairs of muscles of maxilla and mandible, which is less than in larger collembolans such as $O$. cincta (20), A. maritima (17), and T. plumbeus (29). M. sylvatica does not have muscles of labium or labrum, while there are 6 pairs of these in O. cincta and at least 6 pairs in T. plumbeus. $M$. sylvatica has only one pair of dorsal dilators of the oesophagus and no dorsal dilators of the pharynx, which is fewer than in larger collembolans O. cincta (13), T. plumbeus (15).

A total of 51 pairs of muscles were described in the thorax of Neanura muscorum (Bretfeld, 1963) and a total of 37 pairs of muscles were described in the thorax of O. cincta (Bretfeld, 1963). Muscles associated with legs have not been described in that study. We found 36 pairs of muscles not associated with the legs in the thorax of $M$. sylvatica and 17 pairs of muscles associated with legs. There is a greater similarity between the muscles of M. sylvatica and $O$. cincta (both species have greater numbers of dorsoventral muscles) than between the muscles of M. sylvatica and N. muscorum. M. sylvatica lacks several dorsoventral and intersegmental muscles, while the amount of longitudinal muscles remain the same. It is important to note that Bretfeld (1963) described several muscles in the thorax as muscles possibly associated with the head. We describe two of them, Lb dlm1 and Lb dlm2, as dlm 1 and dlm2 in the section on the muscles of the head. A total of 52 pairs and 9 unpaired muscles were described in the abdomen of N. muscorum (Bretfeld, 1963) and a total of 45 pairs of muscles were described in the abdomen of $O$. cincta (Bretfeld, 1963). No muscles associated with the ventral tube, rectum, or anal lobes were described in these collembolans, except one in one species (VTm in O. cincta). We found 43 pairs and one unpaired muscle in the abdomen of $M$. sylvatica, not connected to the ventral tube, as well as 11 pairs of muscles associated with the ventral tube, four with the rectum,

Peer) reviewing PDF | (2019:05:37277:2:0:NEW 2 Oct 2019) 
430

431

432

433

434

435

436

437

438

439

440

441

442

443

444

445

446

447

448

449

450

451

452

453

454

455

456

457

458

459

460

461

462

463

464

465

466

467

468

469

470

471

472

473

474

and two with the anal lobes. As for the thorax, M. sylvatica lacks many dorsoventral muscles, some intersegmental muscles and almost all transverse unpaired muscles.

Minute adult Coleoptera have 19 or 20 pairs of muscles in the head (Sericoderus lateralis and Mikado sp., respectively) and 48 or 49 pairs of muscles in the thorax (Mikado sp. and S. lateralis, respectively) (Polilov \& Beutel, 2009; Polilov \& Beutel, 2010). Compared to them, the number of the head pairs of muscles (24) and thoracic pairs of muscles (51) in M. sylvatica is slightly greater. Larvae of minute Coleoptera have 16 pairs of muscles in the head (Mikado sp. and $S$. lateralis) (Polilov \& Beutel, 2009; Polilov \& Beutel, 2010) and 46 (Mikado sp., first instar larva), 52 (Mikado sp., last instar larva) 63 (S. lateralis, first instar larva) or 64 (S. lateralis, last instar larva) pairs of muscles in the thorax. The number of thoracic pairs of muscles in the minute $M$. sylvatica (51) is close to the number of thoracic muscles in the last instar larvae of Mikado sp., but smaller than in larvae of $S$. lateralis. Minute Hymenoptera have 18 (Megaphragma mymaripenne, Trichogramma evanescens) (Polilov, 2016d; Polilov, 2017), or 20 (Anaphes flavipes) (Polilov, 2016c) muscles in the head and 45 (M. mymaripenne), 50 (A. flavipes), 52 (T. evanescens), or 53 (Gonatocerus morrilli) (Vilhelmsen et al., 2010) muscles in the thorax. Compared to them, the number of the head muscles of M. sylvatica (24) is slightly greater, but the number of the thoracic muscles of this species (51) is greater only compared to those of M. mymaripenne and A. flavipes. Minute adult booklice Liposcelis bostrychophila have 33 pairs of muscles in the head and 57 pairs of muscles in the thorax (Polilov, 2016b). The larvae of L. bostrychophila have 29 pairs of muscles in the head and 55 pairs of muscles in the thorax (Polilov, 2016b). Compared to both larvae and adults, the number of the head pairs of muscles (24) and thoracic pairs of muscles (51) of M. sylvatica is notably smaller. Minute adult thrips Heliothrips haemorrhoidalis have 19 pairs of muscles in the head and 60 pairs of muscles in the thorax (Polilov \& Shmakov, 2016). Compared to them, the number of the head pairs of muscles (24) of M. sylvatica is greater, but the number of the thoracic pairs of muscles (51) is notably smaller. Larvae of $H$. haemorrhoidalis have 18 pairs of muscles in the head and 41 pairs of muscles in the thorax (Polilov \& Shmakov, 2016). Compared to them, the number of the head pairs of muscles (24) and thoracic pairs of muscles (51) of M. sylvatica is notably greater. Minute Neuroptera Coniopteryx pygmaea (Randolf et al., 2017) have 46 pairs of muscles in the head. Compared to them, the number of the head pairs of muscles (24) of M. sylvatica is notably smaller.

In all studied microinsects, there are three groups of abdominal muscles: dorsoventral, dorsal longitudinal, and ventral longitudinal (Polilov, 2016a). All three groups are present in the abdomen of $M$. sylvatica.

To sum up, the musculature system of $M$. sylvatica shows minor reductions in the number of muscles compared to larger collembolan species. In the head, absent muscles such as some mandibular retractors or maxillary adductors are not unique, and other muscles, present in $M$. sylvatica, have the same function (Folsom, 1899). In thorax and abdomen, ventral and dorsal longitudinal, and intersegmental muscles are present in full amount in M. sylvatica, but many dorsoventral muscles are absent. Nevertheless, they most likely do not differ in function from the dorsoventral muscles, present in $M$. sylvatica. The reduction in total number of muscles in $M$. sylvatica does not seem to affect any abilities of $M$. sylvatica to move. Studies on microinsects also show that the changes in musculature are minor, and this system is rather conserved (Polilov, 2015a). The number of muscles in $M$. sylvatica is slightly greater than those in most microinsects. 
475

476

477

478

479

480

481

482

483

484

485

486

487

488

489

490

491

492

493

494

495

496

497

498

499

500

501

502

503

504

505

506

507

508

509

510

511

512

513

514

515

516

517

518

519

520
The relative volume of the musculature of $M$. sylvatica is smaller than those of other microinsects of the same size except Coleoptera larvae (Polilov \& Makarova, 2017). The smaller relative volume compared to those of other microinsects could be explained by the absence of flight musculature.

\section{CONCLUSIONS}

We have studied the anatomy of the minute collembolan $M$. sylvatica for the first time. We show that, despite the small body size, some systems (the highly developed elements of the endoskeleton, or the complex musculature system) are not greatly changed compared to larger relatives.

We revealed possible miniaturization effects; most of them are found in microinsects too (the absence of organs of the circulatory system, unpaired ovaries and oviducts of the female reproductive system, absence of midgut musculature and salivary glands, reduction of some muscles).

Finally, we found some unique features in the anatomy of M. sylvatica: two pairs of apertures in the brain with three pairs of muscles going through it.

Reduction in size leads to changes in different organs and organ systems, giving us perspective on physical constrains of size limit. Studying miniaturization can also bring us further understanding on successful diversification of animals. Collembola is a highly diversified group of terrestrial arthropods with many extremely reduced in size species. Therefore, it is crucial to study anatomical changes in other minute collembolans to broaden our knowledge of miniaturization in animals.

\section{ACKNOWLEDGMENTS}

We thank Natalia Kuznetsova (Moscow State Pedagogical University) and Pyotr Petrov (Moscow State University) for their helpful discussions.

\section{REFERENCES}

Altner H, 1968. Die Ultrastruktur der Labialnephridien von Onychiurus quadriocellatus (Collembola). Journal of Ultrastructure Research 24:349-366 DOI: 10.1016/S00225320(68)80042-5

Beutel RG, Haas A. 1998. Larval head morphology of Hydroscapha natans (Coleoptera, Myxophaga) with reference to miniaturization and the systematic position of Hydroscaphidae. Zoomorphology 118:103-116 DOI: 10.1007/s004350050061

Beutel RG, Pohl H, Hunefeld F. 2005. Strepsipteran brain and effect of miniaturization (Insecta). Arthropod Structure and Development 34:301-313 DOI: 10.1016/j.asd.2005.03.001

Bretfeld G. 1963. Zur Anatomie und Embryologie der Rumpfmuskulatur und der abdominalen Anhänge der Collembolen. Zoologische Jahrbücher Anatomie 80:309-384

Bitsch J. 2012. The controversial origin of the abdominal appendage-like processes in immature insects: Are they true segmental appendages or secondary outgrowths? (Arthropoda Hexapoda). Journal of morphology 273:919-931 DOI: 10.1002/jmor.20031

D'Haese CA. 2003. Homology and morphology in Poduromorpha (Hexapoda, Collembola). European Journal of Entomology 101:385-407 DOI: 10.14411/eje.2003.060

Dallai R, Cavallo V, Falso LF, Fanciulli PP. 2000. The fine structure of the male genital organs of Allacma fusca (L.) (Collembola, Symphypteona). Pedobiologia 44 (3-4):202-209 DOI: 10.1078/S0031-4056(04)70040-2 
521 Dallai R, Zizzari ZV, Fanciulli PP. 2008. Fine structure of the spermatheca and of the accessory

522

523

524

525

526

527

528

529

530

531

532

533

534

535

536

537

538

539

540

541

542

543

544

545

546

547

548

549

550

551

552

553

554

555

556

557

558

559

560

561

562

563

564 glands in Orchesella villosa (Collembola, Hexapoda). Journal of Morphology 269:464478 DOI: 10.1002/jmor.10595

Davies WM. 1927. On the tracheal system of Collembola, with special reference to that of

Sminthurus viridis Lubb. The Quarterly Journal of Microscopical Science, N.S. 281:15-30

Denis JR. 1928. Études sur l'anatomie de la tête de quelques collemboles suivies de considérations sur la morphologie de la tête des insectes. Archives de Zoologie Experimentale et Générale 68:1-291

Dunlop J. 2019. Miniaturisation in Chelicerata. Arthropod Structure and Development 48:20-34 DOI: $10.1016 /$ j.asd.2018.10.002

Eberhard WG, Wcislo WT. 2011. Grade changes in brain-body allometry: morphological and behavioural correlates of brain size in miniature spiders, insects and other invertebrates. Advances in Insect Physiology 40:155-214. DOI:10.1016/B978-0-12-387668-3.00004-0

Eisenbeis G, Wichard W. 1975. Feinstruktureller und histochemischer Nachweis des Transportepithels am Ventraltubus symphypleoner Collembolen (Insecta, Collembola). Zeitschrift für Morphologie der Tiere 81:103-110

Fernald HT. 1890. The relationships of Arthropods. Studies from the Biological Laboratory of Johns Hopkins University 4:431-513

Folsom JW. 1899. The anatomy and physiology of the mouth-parts of the Collembola Orchesella cincta L. Bulletin of the Museum of Comparative Zoology at Harvard College 35 (2):7-39

Friedrich F, Beutel RG. 2008. The thorax of Zorotypus (Hexapoda, Zoraptera) and a new nomenclature for the musculature of Neoptera. Arthropod Structure and Development 37:29-54 DOI: 10.1016/j.asd.2007.04.003

Gross V, Treffkorn S, Reichelt J, Epple L, Lüter C, Mayer G. 2019. Miniaturization of tardigrades (water bears): Morphological and genomic perspectives. Arthropod Structure and Development 48:12-19 DOI: 10.1016/j.asd.2018.11.006

Hanken J, Wake DB. 1993. Miniaturization of body size: organismal consequences and evolutionary significance. The Annual Review of Ecology, Evolution, and Systematics 24:501-19 DOI:10.1146/annurev.es.24.110193.002441

Hoffmann RW. 1908. Uber die Morphologie und die Funktion der Kauwerkzeuge und uber des Kopfnervensystem von Tomocerus plumbeus L. III Beitrag zur KennPstis der Collembolen. Zeitschrift für wissenschaftliche Zoologie 89:598-689

Hopkin SP. 1997. Biology of the Springtails (Insecta: Collembola). Oxford University Press, Oxford, UK

Humbert W. 1975. Ultrastructure des Nephrocytes cephaliques et abdominaux chez Tomocerus minor (Lubbock) et Lepidocyrtus curvicollis Bourlet (Collemboles). International Journal of Insect Morphology and Embryology 4:307-318 DOI: 10.1016/0020-7322(75)90019-7

Humbert W. 1979. The midgut of Tomocerus minor Lubbock (Insecta, Collembola): ultrastructure, cytochemistry, ageing and renewal during a moulting cycle. Cell and Tissue Research 196:39-57 DOI: 10.1007/BF00236347

Imms AD. 1939. On the antennal musculature in insects and other arthropods. The Quarterly Journal of Microscopical Science 2:273-320

Imms AD. 1957. A general textbook of Entomology, 10th edn., revised by O. W. Richards and R. G. Davies. London: Methuen 
565

566

567

568

569

570

571

572

573

574

575

576

577

578

579

580

581

582

583

584

585

586

587

588

589

590

591

592

593

594

595

596

597

598

599

600

601

602

603

604

605

606

607

608

609
Jałoszyński P, Hünefeld F, Beutel RG. 2012. The evolution of "deformed” brains in ant-like stone beetles (Scydmaeninae, Staphylinidae). Arthropod Structure and Development 41 (1):17-28 DOI: 10.1016/j.asd.2011.07.003

Jordana R, Baquero E, Montuenga LM. 2000. A new type of arthropod photoreceptor. Arthropod Structure and Development 29 (4):289-293

Koch M. 2000. The cuticular cephalic endoskeleton of primarily wingless hexapods: ancestral state and evolutionary changes. Pedobiologia 44:374-385

Kollmann M, Huetteroth W, SchachPster J. 2011. Brain organization in Collembola (springtails). Arthropod Structure and Development 40:304-316 DOI: 10.1016/j.asd.2011.02.003

Lécaillon A. 1902a. Sur Ie testicule d'Anurida maritima. Bulletin de la Société entomologique de France 7(4):64-67

Lécaillon A. 1902b. Sur le testicule d'Anurophorus laricis Nie. Bulletin de la Sociiti Philomatique de Paris 4:46-52

Lubbock J. 1873. Monograph of the Collembola and Thysanura. Ray Society, London.

Minelli A, Fusco G. 2019. No limits: Breaking constrains in insect miniaturization. Arthropod Structure \& Development. 48:4-11 DOI: 10.1016/j.asd.2018.11.009

Mukerji D. 1932. Description of a new species of Collembola and its anatomy. Record of Indian Museum 34:47-49

Philiptschenko J. 1907. Anatomische Studien über Collembola. Zeitschrift für wissenschaftliche Zoologie 85:270-304

Polilov AA. 2005. Anatomy of the feather-winged beetles Acrotrichis montandoni and Ptilium myrmecophilum (Coleoptera, Ptiliidae). Entomological Review 85:467-475

Polilov AA. 2008. Anatomy of the smallest of the Coleoptera, feather-winged beetles from tribe Nanosellini (Coleoptera, Ptiliidae) and limits to insect miniaturization. Zoologicheskii Zhurnal 87(2):181-188 [Entomological Review 2008; 88(1): 26-33]

Polilov AA, Beutel, RG. 2009. Miniaturization effects in larvae and adults of Mikado sp. (Coleoptera: Ptiliidae), one of the smallest free-living insects. Arthropod Structure and Development 38:247-270 DOI: 10.1016/j.asd.2008.11.003

Polilov AA, Beutel RG. 2010. Developmental stages of the hooded beetle Sericoderus lateralis (Coleoptera: Corylophidae) with comments on the phylogenetic position and effects of miniaturization. Arthropod Structure and Development 39:52-69 DOI: 10.1016/j.asd.2009.08.005

Polilov AA. 2012. The smallest insects evolve anucleate neurons. Arthropod Structure and Development 41:29-34 DOI: 10.1016/j.asd.2011.09.001

Polilov AA. 2015a. Small is beautiful: features of the smallest insects and limits to miniaturization. The Annual Review of Entomology 60:103 - 121 DOI: 10.1146/annurevento-010814-020924

Polilov AA. 2015b. Consequences of miniaturization in insect morphology. Moscow University Biological Sciences Bulletin 70 (3):136-142 DOI: 10.3103/S0096392515030098

Polilov AA. 2016a. At the size limit - effects of miniaturization in insects. Springer International Publishing. DOI: 10.1007/978-3-319-39499-2

Polilov AA. 2016b. Anatomy of adult and first instar nymph of book lice Liposcelis bostrychophila (Psocoptera: Liposcelididae). Zoologicheskii Zhurnal 95(11):1305-1321. [Entomological Review 96(9):1165-1181]. DOI: 10.7868/S0044513416090087. 
610

611

612

613

614

615

616

617

618

619

620

621

622

623

624

625

626

627

628

629

630

631

632

633

634

635

636

637

638

639

640

641

642

643

644

645

646

647

648

649

650

651

652

653

654

655

Polilov AA. 2016c. Features of the structure of Hymenoptera associated with miniaturization: 1. Anatomy of the fairyfly Anaphes flavipes (Hymenoptera, Mymaridae). Zoologicheskii Zhurnal 95(5):567-578. [Entomological Review 96 (4):407 -418]. DOI: $10.7868 / \mathrm{S} 004451341605010 \mathrm{X}$

Polilov AA. 2016d. Features of the structure of Hymenoptera associated with miniaturization: 2. Anatomy of the Trichogramma evanescens (Hymenoptera, Trichogrammatidae). Zoologicheskii Zhurnal 95(6):699-711. [Entomological Review 96 (4):419 -431]. DOI: 10.7868/S0044513416060155

Polilov AA. 2017. Anatomy of adult Megaphragma (Hymenoptera: Trichogrammatidae), one of the smallest insects, and new insight into insect miniaturization. PLOS One 12

(5):e0175566 DOI: 10.1371/journal.pone.0175566

Polilov AA, Shmakov AS. 2016. The anatomy of the thrips Heliothrips haemorrhoidalis (Thysanoptera, Thripidae) and its specific features caused by miniaturization. Arthropod Structure and Development 45:496 -507 DOI: 10.1016/j.asd.2016.09.002

Polilov AA, Makarova AA. 2017. The scaling and allometry of organ size associated with miniaturization in insects: A case study for Coleoptera and Hymenoptera. Scientific Reports 7:43-95 DOI: 10.1038/srep43095

Polilov AA, Makarova AA, Kolesnikova UK. 2019. Cognitive abilities with a tiny brain: neuronal structures and associative learning in the minute Nephanes titan (Coleoptera: Ptiliidae). Arthropod Structure and Development 48:98-102 DOI: 10.1016/j.asd.2018.11.008

Prowazek S. 1900. Bau und Entwicklung der Collembolen. Arbeiten aus dem Zoologischen Instituten der Universität Wien und der Zoologischen Station in Triest 12:335-370

Randolf S, Zimmermann D, Aspöck U. 2017. Head anatomy of adult Coniopteryx pygmaea Enderlein 1906: effects of miniaturization and the systematic position of Coniopterygidae (Insecta: Neuroptera). Arthropod Structure and Development 46:304-322 DOI: 10.1016/j.asd.2016.12.004

Schaller F. 1970. 1. Collembola (Springschwanze). Handbuch der Zoologie, Berlin 4(2)

Snodgrass R. 1935. Principles of insect morphology. New York: McGraw-Hill Book Company van der Woude E, Martinus EH, Smid HM. 2018. Differential effects of brain size on memory performance in parasitic wasps Animal Behaviour, 141:57-66 DOI: 10.1016/j.anbehav.2018.05.011

Verhoef HA, Bosman C, Bierenbroodspot A, Boer HH. 1979. Ultrastructure and function of the labial nephridia and the rectum of Orchesella cinta (L) (Collembola). Cell and tissue research 198 (2):237-246

Vilhelmsen L, Mikó I, Krogmann L. 2010. Beyond the wasp-waist: Structural diversity and phylogenetic significance of the mesosoma in apocritan wasps (Insecta: Hymenoptera). Zoological Journal of the Linnean Society 159:22-194 DOI: 10.1111/j.10963642.2009.00576.x

Willem V. 1900. Recherche sur les Collemboles et les Thysanoures. Mémoires couronnés et mémoires des savants étrangers / publiés par l'Académie royale des sciences, des lettres et des beaux-arts de Belgique 58:1-144

Willem V, Sabbe H. 1897. Le tube ventral et les glandes cephaliques des Sminthures. Annales de la Société entomologique de Belgique 41:130-132

Wipfler B, Machida R, Müller B, Beutel RG. 2011. On the head morphology of Grylloblattodea (Insecta) and the systematic position of the order - with a new nomenclature for the head 
656 muscles of Dicondylia. Systematic Entomology 36:241-66 DOI: 10.1111/j.1365$657 \quad 3113.2010 .00556 . x$

658 Wolter H. 1963. Vergleichende Untersuchungen zur Anatomie und Funktionsmorphologie der

659

660

661

662

663

664 stechend-saugenden Mundwerkzeuge der Collembolen. Zoologische Jahrbücher, Anatomie $81: 27-100$

Yavorskaya MI, Anton E, Jałoszyński P, Polilov A, Beutel RG. 2018. Cephalic anatomy of Sphaeriusidae and a morphology-based phylogeny of the suborder Myxophaga (Coleoptera). Systematic Entomology 43:777-797 DOI: 10.1111/syen.12304

Zimdars B, Dunger W. 1994. Synopses on Palaearctic Collembola. Volume 1. Tullberginae. Abhandlungen und Berichte des Naturkundemuseums Görlitz 68 


\section{Figure 1}

Habitus of Mesaphorura sylvatica, SEM

(A) lateral view; (B) ventral view; (C) dorsal view; ao - anal opening, as - anal spine, cx1, 2, 3 - pro-, meso-, and metacoxae, go - genital opening, PAO - postantennal organ, sx1, 2, 3 - pro-, meso, and metasubcoxae, vl - ventral line, VT - ventral tube. Furcula and eyes are absent.

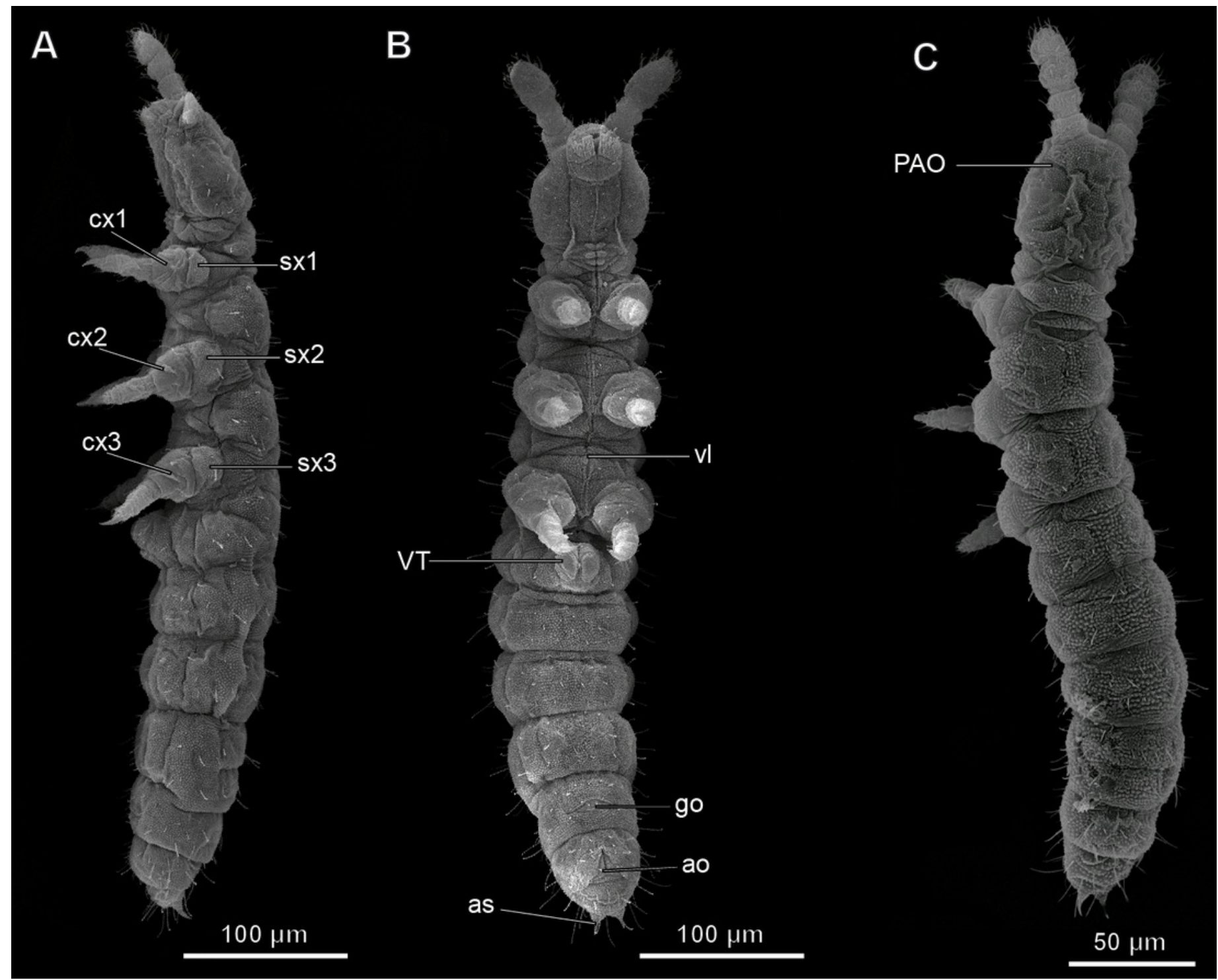




\section{Figure 2}

Internal morphology of Mesaphorura sylvatica, 3D

Colors: blue - cuticle, light blue - tentorium, green - digestive system, yellow - central nervous system, brown - musculature, purple - reproductive system, dark violet excretory system: (A) lateral internal view; (B) lateral external view; (C) ventral view; (D) dorsal view; An - antennae, cer - brain, cx1, 2, 3 - pro-, meso-, and metacoxae, eg ovary lobe with eggs, en 1 - endosternite, fur1, 2, 3 - pro-, meso-, and metafurca-like structures, gg1, 2, 3+ag - pro-, meso-, and metathoracic+abdominal ganglia, lanephr labial nephridia, mg - midgut, $\mathrm{Mn}$ - mandible, $\mathrm{Mx}$ - maxilla, oes - oesophagus, ova ovary lobe without eggs, pst - pseudotentorium, rt - rectum, soeg - suboesophageal ganglion, VT - ventral tube. Paired structures (maxillae, mandible, labial nephridia, muscles) are shown on the right side only. 

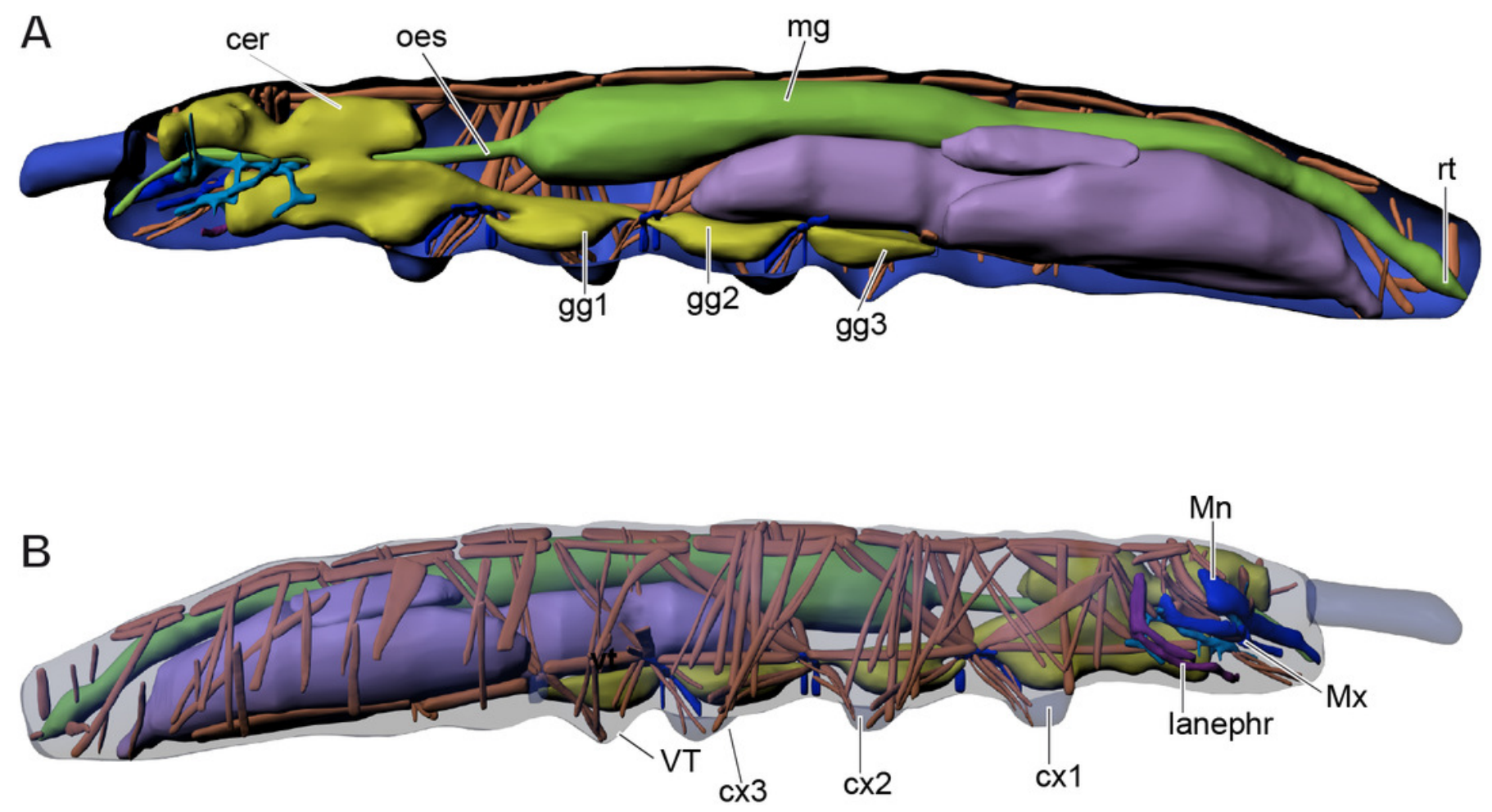

C

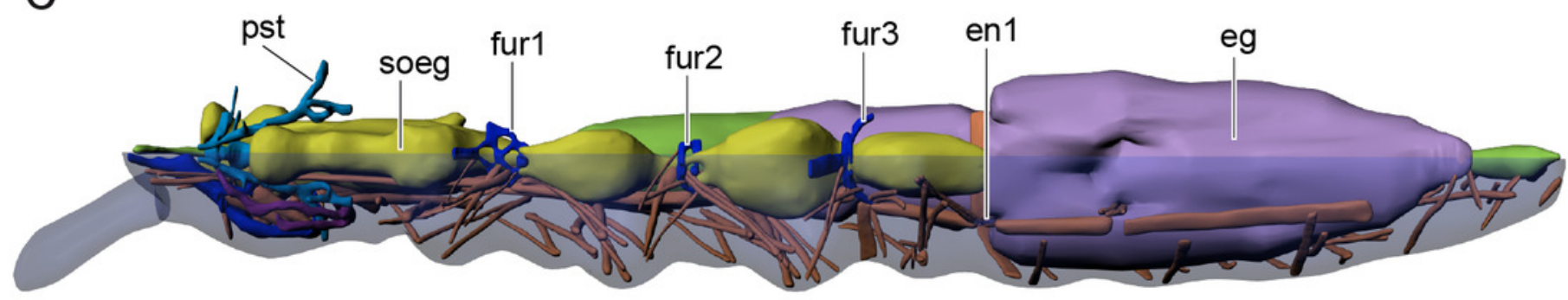

D

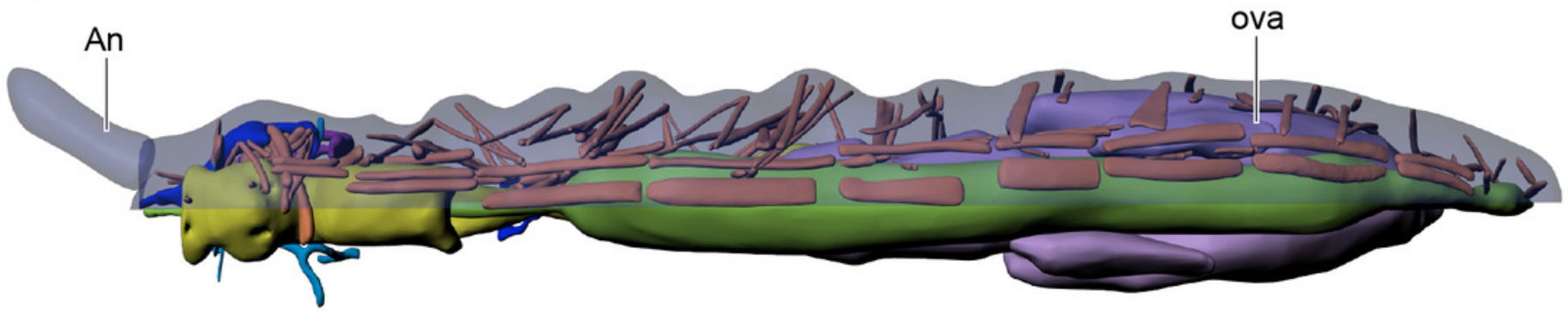

$100 \mu \mathrm{m}$ 


\section{Figure 3}

Anatomy of head in Mesaphorura sylvatica, 3D

$(A, F)$ dorsolateral view, $(B, C, E)$ lateral internal view, (D) lateral external view. An antennae, bp - body of pseudotentorium, ca - connecting arm, car - cardo, ce - chitinous expansion, cer - cerebrum, dsa - dorsal suspensory arm, fo - foot, ful - fulcrum, la lateral arm, Mn - mandible, Mx - maxillae, oes - oesophagus, pst - pseudotentorium, soeg - suboesophagal ganglion, st - stipes. Musculature see text. Paired structures (maxillae, mandible, muscles, except: 1(Oe), 1(Pst), 2(Pst) in E-F) are shown on the right side only. 

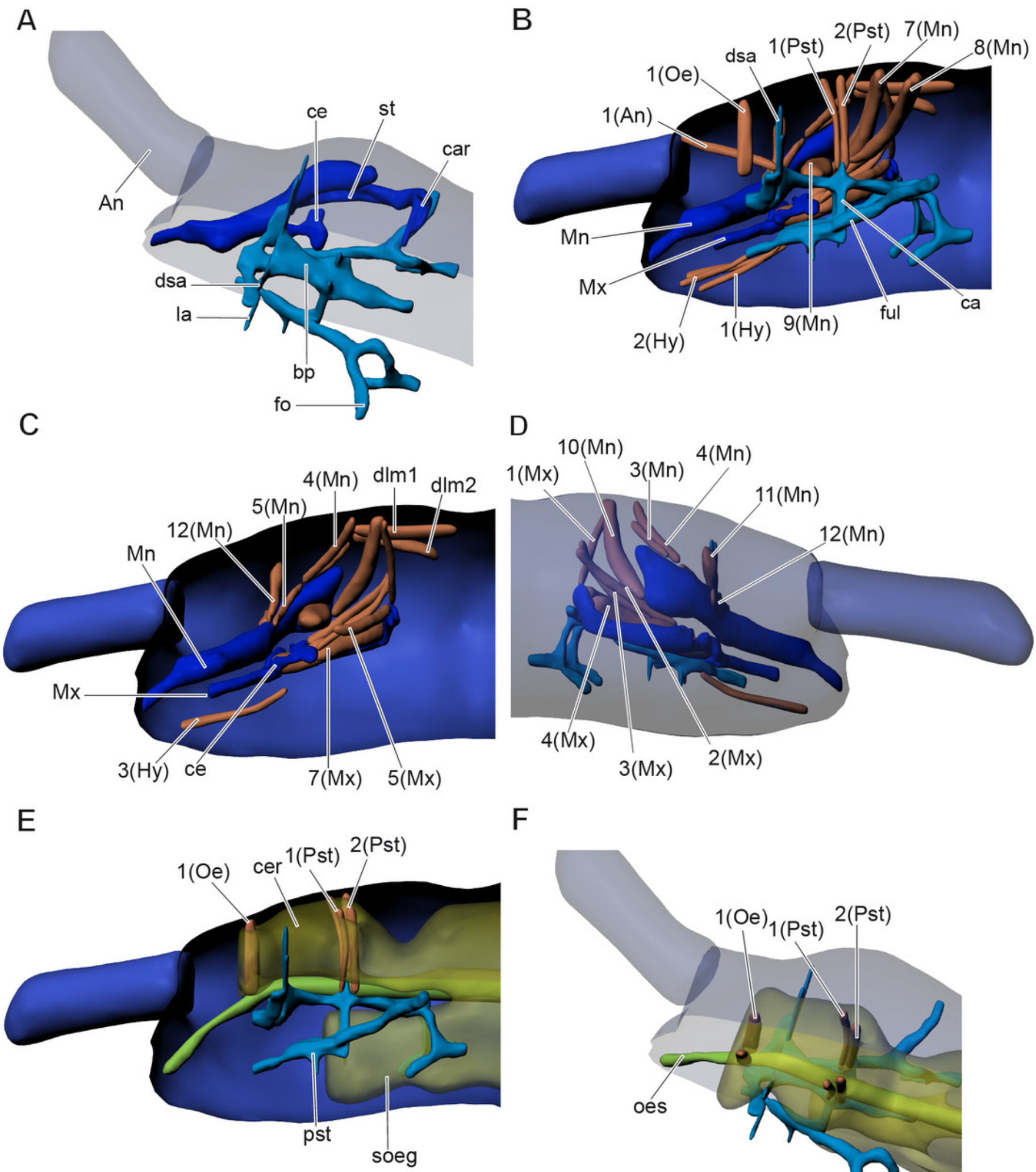

$\mathrm{F}$

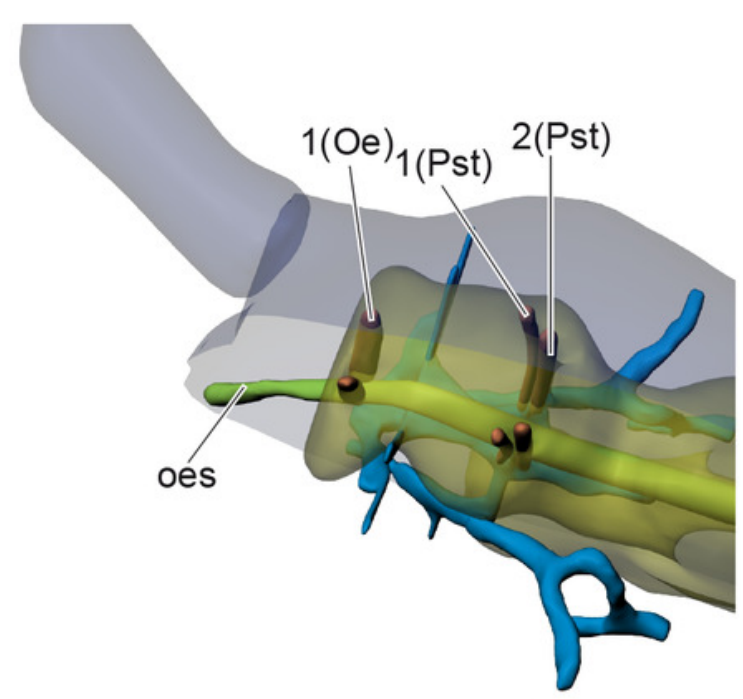

$40 \mu \mathrm{m}$ 


\section{Figure 4}

Digestive and excretory (A, B), nervous (C, D), and reproductive $(E, F)$ systems of Mesaphorura sylvatica, 3D

$(A, C, E)$ lateral view; $(B, D, F)$ dorsal view. cer - brain, eg - ovary lobe with eggs, gg1, 2, 3+ag - pro-, meso-, and metathoracic+abdominal ganglia, lanephr - labial nephridia, mg midgut, oes - oesophagus, ova - ovary lobe without eggs, rt - rectum, soeg suboesophageal ganglion, va - vagina. Paired structures (labial nephridia) are shown on the right side only. 

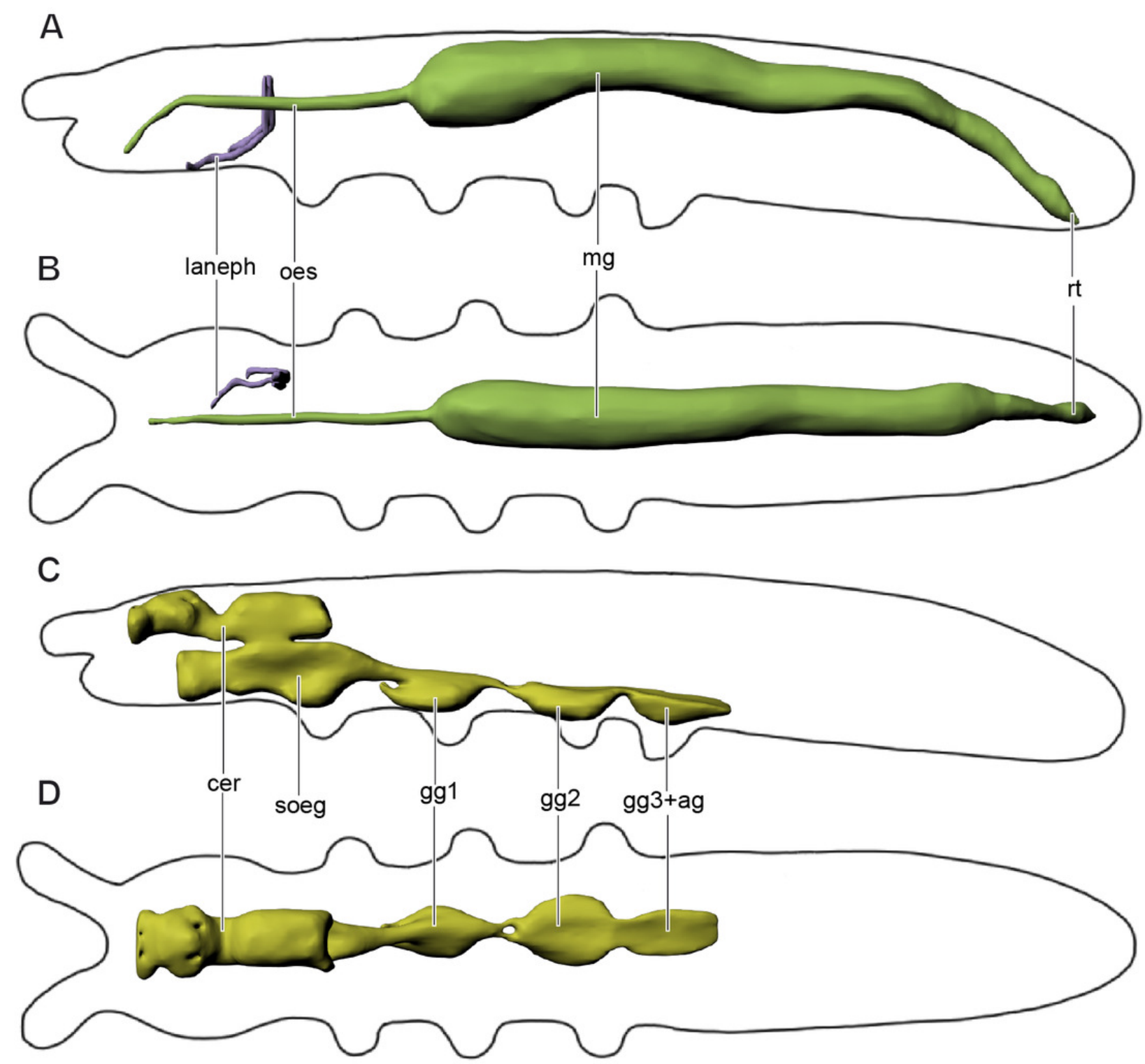

E

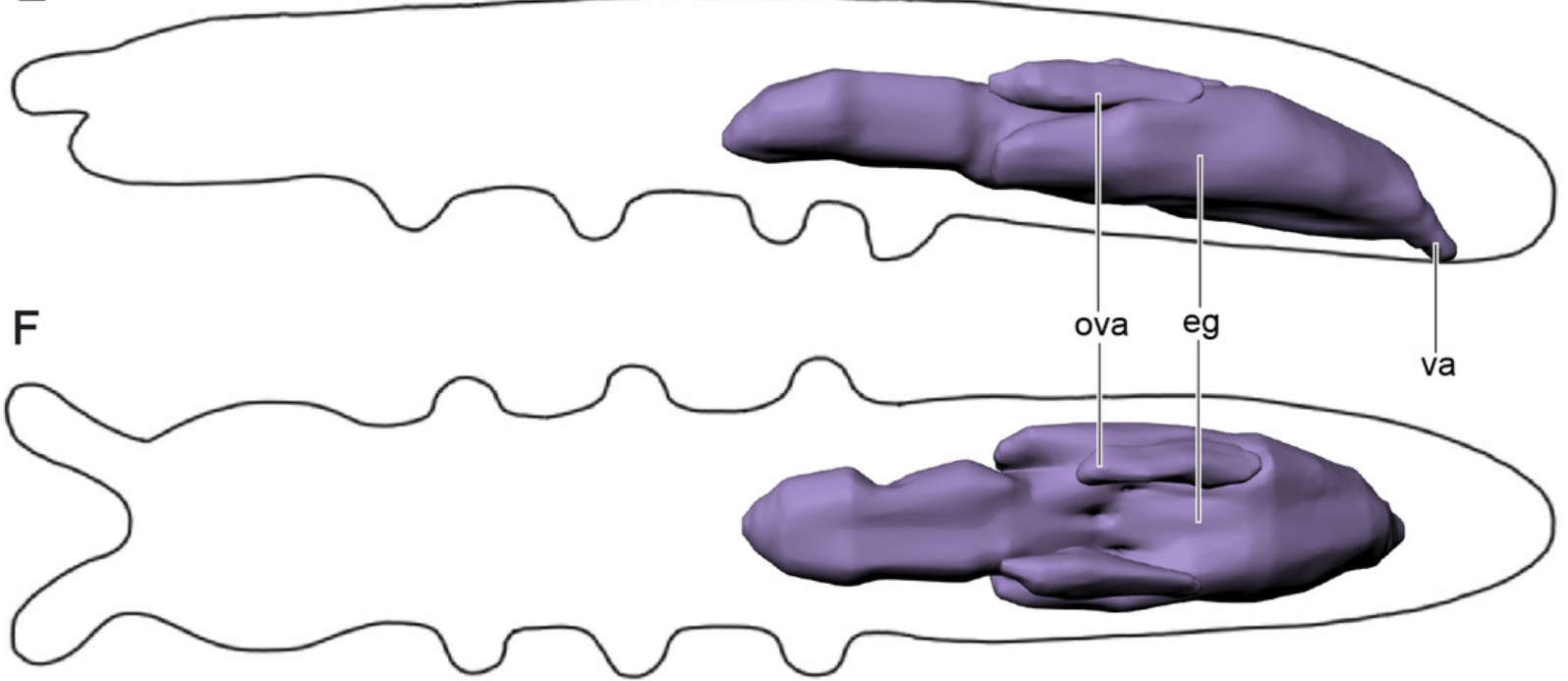

Peer) reviewing PDF | (2019:05:37277:2:0:NEW 2 Oct 2019) 
Figure 5

Musculature of thorax in Mesaphorura sylvatica, 3D

(A - C) lateral internal view. cx1, 2, 3 - pro-, meso-, and metacoxae, fur1, 2, 3 - pro-, meso-, and metafurca-like structures, pst - pseudotentorium. Musculature see text. 


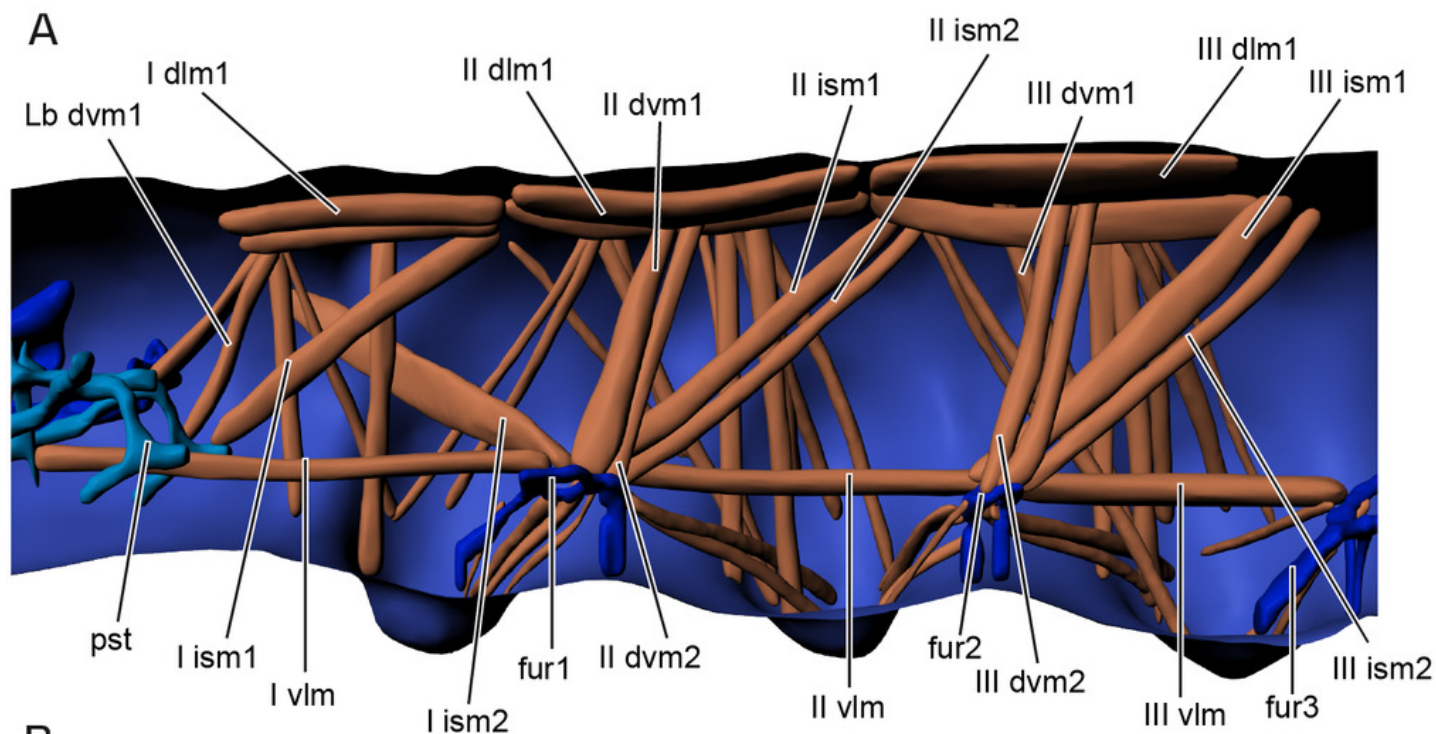

B
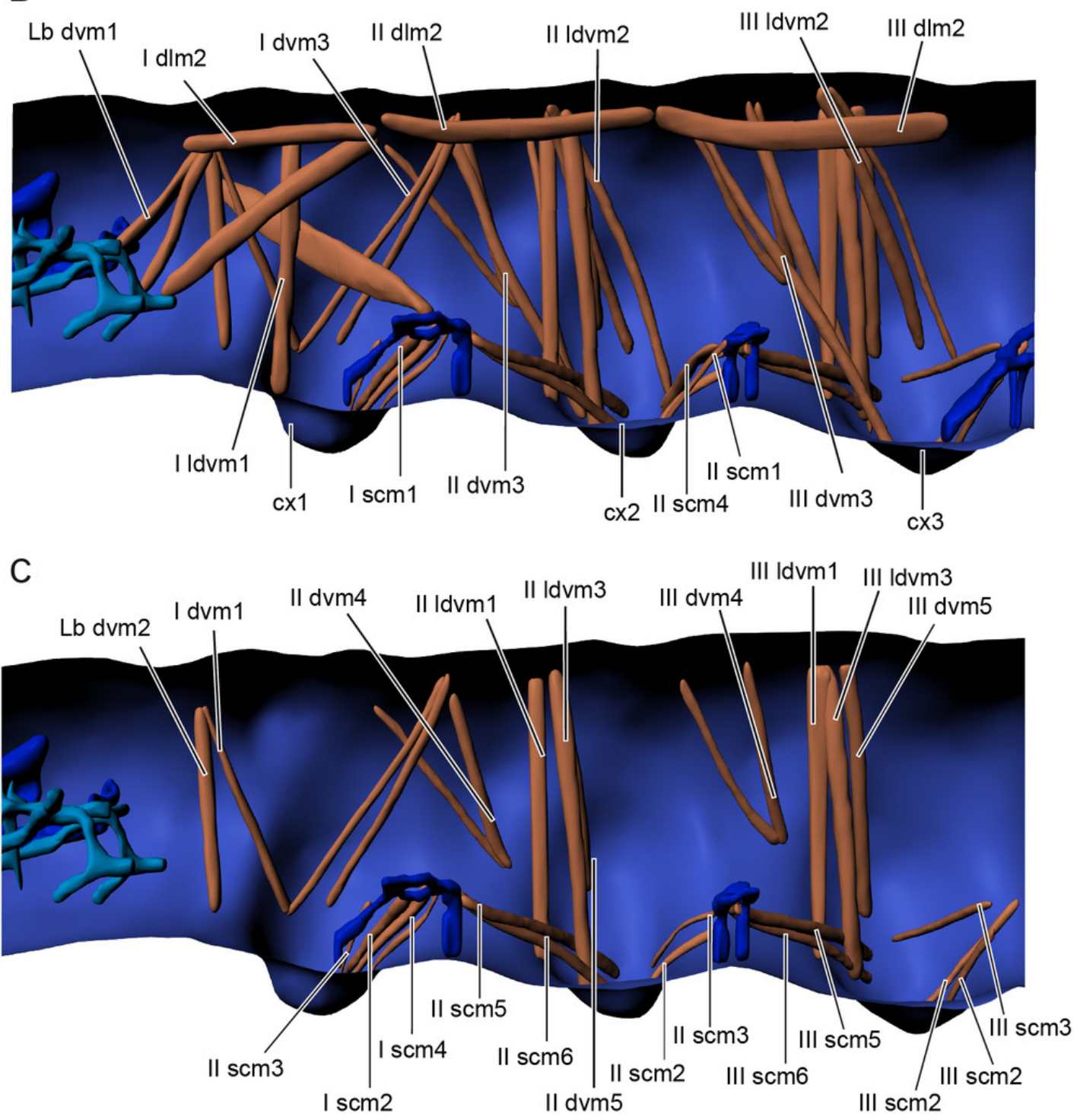
Figure 6

Musculature of abdomen in Mesaphorura sylvatica, 3D

(A - B) lateral internal view. fur3 - metafurca-like structure, en - endosternite.

Musculature see text. 


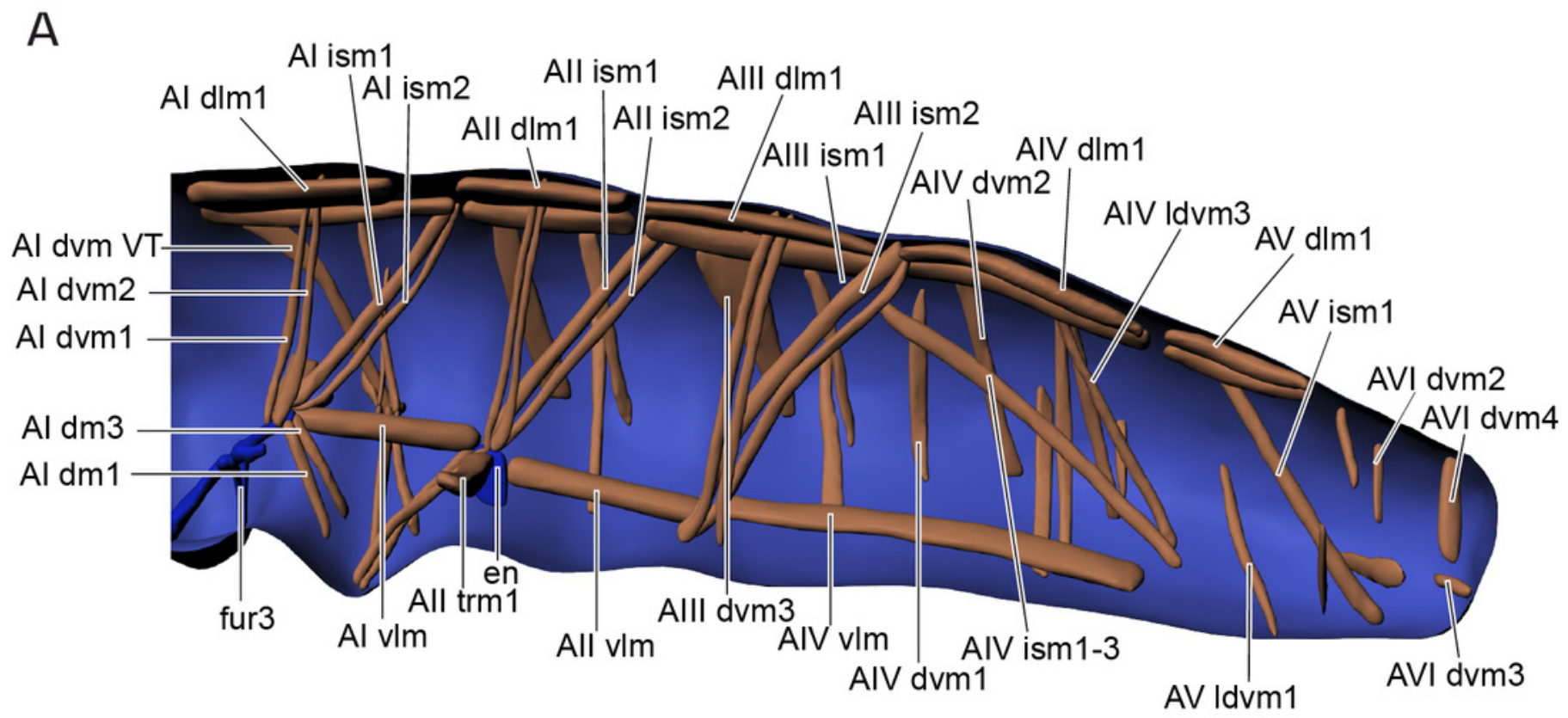

B

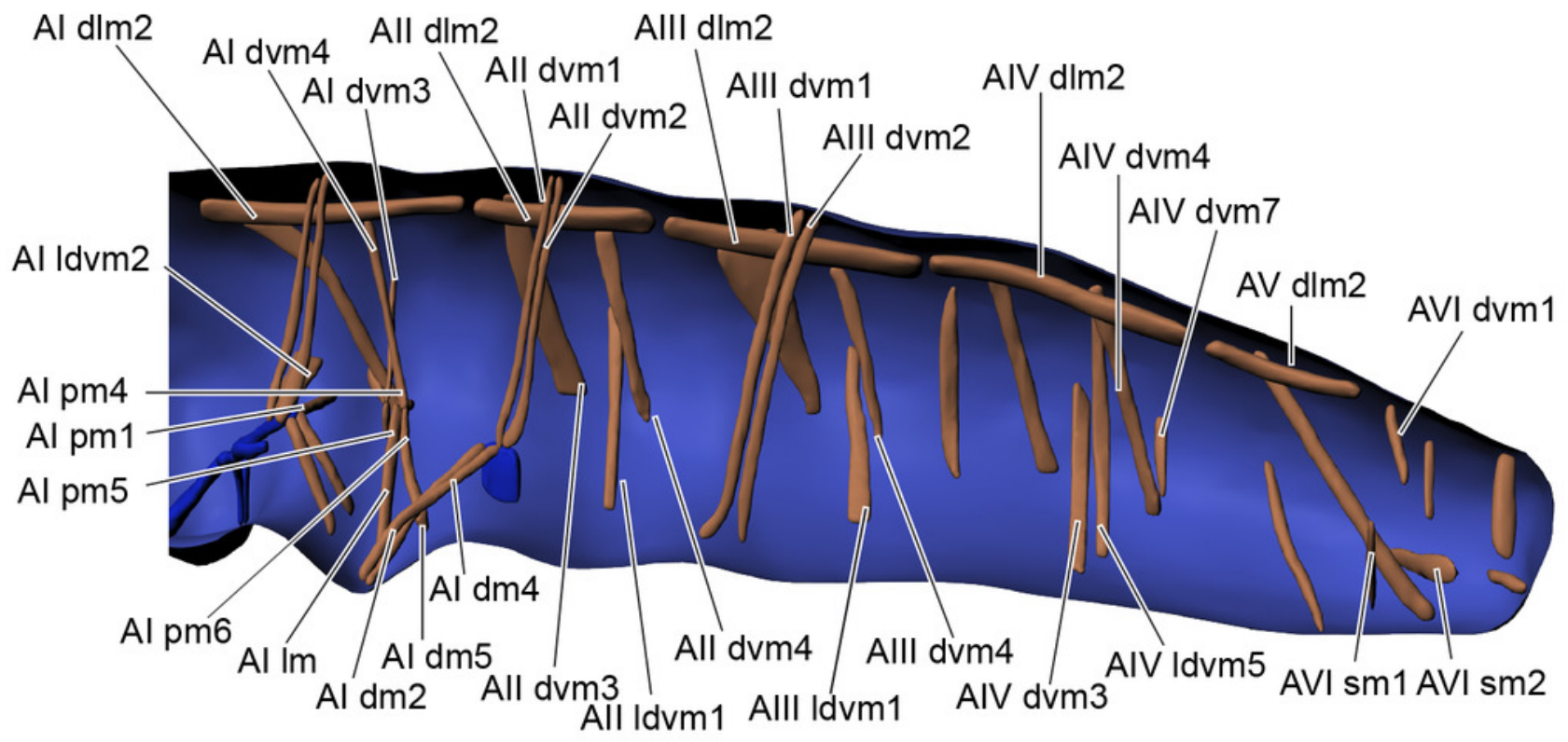

$40 \mu \mathrm{m}$ 
Table $\mathbf{1}$ (on next page)

Head muscle origins and insertions. 


\begin{tabular}{|c|c|c|c|}
\hline Abbrev. & Name & Origin & Insertion \\
\hline 1 (Pst) & M. craniotentorialis lateralis & $\begin{array}{l}\text { medial surface of frons, laterad } \\
\text { of } 2 \text { (Pst) }\end{array}$ & $\begin{array}{l}\text { dorsal surface of pseudotentorial } \\
\text { plate, laterad of } 2 \text { (Pst) }\end{array}$ \\
\hline 2(Pst) & M. craniotentorialis medialis & $\begin{array}{l}\text { medial surface of frons, mediad } \\
\text { of } 1 \text { (Pst) }\end{array}$ & $\begin{array}{l}\text { dorsal surface of pseudotentorial } \\
\text { plate, mediad of } 1 \text { (Pst) }\end{array}$ \\
\hline $1(\mathrm{An})$ & M. antennotentorialis & $\begin{array}{l}\text { lateral face of first antennal } \\
\text { segment }\end{array}$ & pseudotentorium \\
\hline $3(\mathrm{Mn})$ & $\begin{array}{l}\text { M. craniomandibularis } \\
\text { posterior }\end{array}$ & posterior surface of gena & $\begin{array}{l}\text { dorsolateral surface of basal ridge of } \\
\text { mandible, posterad of } 4(\mathrm{Mn})\end{array}$ \\
\hline 4(Mn) & $\begin{array}{l}\text { M. craniomandibularis } \\
\text { anterior }\end{array}$ & frons, mediad of $3(\mathrm{Mn})$ & $\begin{array}{l}\text { dorsolateral surface of basal ridge of } \\
\text { mandible, anteriad of } 3(\mathrm{Mn}), \\
\text { posteriad of } 5(\mathrm{Mn})\end{array}$ \\
\hline $5(\mathrm{Mn})$ & M. tentoriomandibularis 1 & anterior arm of pseudotentorium & $\begin{array}{l}\text { dorsolateral surface of mandible, } \\
\text { anteriad of } 4(\mathrm{Mn})\end{array}$ \\
\hline $7(\mathrm{Mn})$ & M. craniomandibularis 1 & $\begin{array}{l}\text { frons, along with } 1(\mathrm{Mx}), \text { mediad } \\
\text { of } 10(\mathrm{Mn})\end{array}$ & $\begin{array}{l}\text { ventroposterior area, outer angle of } \\
\text { large triangular opening of mandible } \\
\text { along with } 8(\mathrm{Mn}), 10(\mathrm{Mn})\end{array}$ \\
\hline $8(\mathrm{Mn})$ & M. craniomandibularis 2 & $\begin{array}{l}\text { posterior surface of frons, } \\
\text { crossing median plane, } \\
\text { posteriad of } 7(\mathrm{Mn})\end{array}$ & $\begin{array}{l}\text { ventroposterior area, outer angle of } \\
\text { large triangular opening of mandible } \\
\text { along with } 7(\mathrm{Mn}), 10(\mathrm{Mn})\end{array}$ \\
\hline $9(\mathrm{Mn})$ & M. tentoriomandibularis 2 & base of pseudotentorium & $\begin{array}{l}\text { large triangular opening (median } \\
\text { surface) of mandible }\end{array}$ \\
\hline $10(\mathrm{Mn})$ & M. craniomandibularis 3 & frons, laterad of $7(\mathrm{Mn})$ & $\begin{array}{l}\text { ventroposterior area, outer angle of } \\
\text { large triangular opening of mandible } \\
\text { along with } 7(\mathrm{Mn}), 8(\mathrm{Mn})\end{array}$ \\
\hline $11(\mathrm{Mn})$ & M. craniomandibularis 4 & $\begin{array}{l}\text { anterior surface of area } \\
\text { antennalis, near antennal base, } \\
\text { ventrad of } 12(\mathrm{Mn})\end{array}$ & $\begin{array}{l}\text { lateral surface of mandible, laterad } \\
\text { of } 12(\mathrm{Mn})\end{array}$ \\
\hline 12(Mn) & M. craniomandibularis 5 & $\begin{array}{l}\text { anterior surface of area } \\
\text { antennalis, dorsad of } 11(\mathrm{Mn})\end{array}$ & $\begin{array}{l}\text { lateral surface of mandible, mediad } \\
\text { of } 11(\mathrm{Mn})\end{array}$ \\
\hline $1(\mathrm{Mx})$ & M. craniocardinalis & dorsomedial area of occiput & $\begin{array}{l}\text { lateral edge of cardo, dorsad of } \\
5(\mathrm{Mx})\end{array}$ \\
\hline $2(\mathrm{Mx})$ & M. craniostipitalis medialis & $\begin{array}{l}\text { posterior surface of gena, } \\
\text { ventrad of } 3(\mathrm{Mx})\end{array}$ & $\begin{array}{l}\text { lateral edge of chitinous expansion, } \\
\text { mediad of } 3(\mathrm{Mx})\end{array}$ \\
\hline $3(\mathrm{Mx})$ & M. craniofurcalis lateralis & $\begin{array}{l}\text { posterior surface of gena, dorsad } \\
\text { of } 2(\mathrm{Mx})\end{array}$ & $\begin{array}{l}\text { median edge of chitinous expansion, } \\
\text { laterad of } 2(\mathrm{Mx})\end{array}$ \\
\hline $4(\mathrm{Mx})$ & M. maxillaris internus 1 & anterior surface of cardo & $\begin{array}{l}\text { dorsoventral surface of chitinous } \\
\text { expansion }\end{array}$ \\
\hline $5(\mathrm{Mx})$ & M. tentoriocardinalis & base of pseudotentorium & $\begin{array}{l}\text { concavity of cardo, ventrad of } \\
1(\mathrm{Mx})\end{array}$ \\
\hline $7(\mathrm{Mx})$ & M. maxillaris internus 2 & median surface of stipes & $\begin{array}{l}\text { dorsolateral surface of chitinous } \\
\text { expansion }\end{array}$ \\
\hline $\begin{array}{l}1- \\
3(\mathrm{Hy})\end{array}$ & M. craniohypopharyngealis & $\begin{array}{l}\text { anterioventral area of the head } \\
\text { capsule }\end{array}$ & hypopharynx \\
\hline $1(\mathrm{Oe})$ & M. cranioesophagialis & $\begin{array}{l}\text { anteriomedial surface of area } \\
\text { antennalis }\end{array}$ & dorsal surface of oesophagus \\
\hline $\mathrm{d} \operatorname{lm} 1$ & $\begin{array}{l}\text { M. occiputo-cranialis } \\
\text { medialis }\end{array}$ & occiput, mediad of dlm2 & $\begin{array}{l}\text { medial surface of frons, mediad of } \\
\text { dlm2 }\end{array}$ \\
\hline $\mathrm{d} \operatorname{lm} 2$ & $\begin{array}{l}\text { M. occiputo-cranialis } \\
\text { lateralis }\end{array}$ & occiput, laterad of dlm 1 & $\begin{array}{l}\text { medial surface of frons, laterad of } \\
\text { dlm1 }\end{array}$ \\
\hline
\end{tabular}


Table 2 (on next page)

Thoracic muscle origins and insertions. 
1

\begin{tabular}{|c|c|c|c|}
\hline Abbrev. & Name & Origin & Insertion \\
\hline I d lm 1 & $\begin{array}{l}\text { M. antecosta-occipitalis } \\
\text { medialis }\end{array}$ & antecosta I, mediad of I dlm2 & occiput, mediad of I dlm2 \\
\hline I d $\operatorname{lm} 2$ & $\begin{array}{l}\text { M. antecosta-occipitalis } \\
\text { lateralis }\end{array}$ & antecosta I, laterad of I dlm 1 & occiput, laterad of I dlm1 \\
\hline I vlm & M. profurca-pseudotentoralis & $\begin{array}{l}\text { anterior part of profurca-like } \\
\text { structure }\end{array}$ & union arm of pseudotentorium \\
\hline I ism1 & M. antecosta-pseudotentoralis & antecosta I & posterior area of fulcrum \\
\hline I ism2 & M. profurca-occipitalis & $\begin{array}{l}\text { dorsal part of profurca-like } \\
\text { structure }\end{array}$ & dorsolateral area of occiput \\
\hline I dvm1 & M. cervico-coxalis & dorsolateral cervical membrane & anterior procoxal rim \\
\hline I dvm3 & $\begin{array}{l}\text { M. pronoto-coxalis lateralis; } \\
\text { two bands }\end{array}$ & anterior region of pronotum & $\begin{array}{l}\text { lateral procoxal rim and anterior } \\
\text { procoxal rim along with } \\
\text { instertion of I dvm } 2\end{array}$ \\
\hline I ldvm1 & M. pronoto-coxalis medialis & anterolateral part of pronotum & anterior procoxal rim \\
\hline Lb dvm1 & $\begin{array}{l}\text { M. occiputo-pseudotentoralis; } \\
\text { two bands }\end{array}$ & dorsal area of occipitale & posterior area of fulcrum \\
\hline Lb dvm2 & M. occiputo-cervicalis & dorsal area of occipitale & ventral cervical membrane \\
\hline I scm 1 & M. profurca-coxalis 1 & $\begin{array}{l}\text { anterior face of profurca-like } \\
\text { structure }\end{array}$ & $\begin{array}{l}\text { posterior procoxal rim, laterad of } \\
\text { I scm } 2\end{array}$ \\
\hline I scm2 & M. profurca-coxalis 2 & $\begin{array}{l}\text { ventral face of profurca-like } \\
\text { structure }\end{array}$ & $\begin{array}{l}\text { posterior procoxal rim, mediad of } \\
\text { I scm } 1\end{array}$ \\
\hline I scm3 & M. profurca-coxalis 3 & $\begin{array}{l}\text { ventral face of profurca-like } \\
\text { structure along with I scm } 4\end{array}$ & lateral procoxal rim \\
\hline I scm4 & M. profurca-coxalis 4 & $\begin{array}{l}\text { ventral face of profurca-like } \\
\text { structure along with I scm } 3\end{array}$ & posteriolateral procoxal rim \\
\hline II d $\operatorname{lm} 1$ & $\begin{array}{l}\text { M. antecosta-antecostalis } \\
\text { medialis }\end{array}$ & antecosta II; mediad of II dlm2 & antecosta III; mediad of II dlm2 \\
\hline II d $\operatorname{lm} 2$ & $\begin{array}{l}\text { M. antecosta-antecostalis } \\
\text { lateralis }\end{array}$ & antecosta II; laterad of II dlm1 & antecosta III; laterad of II dlm1 \\
\hline II vlm & M. profurca-mesofurcalis & $\begin{array}{l}\text { lateral part of profurca-like } \\
\text { structure }\end{array}$ & $\begin{array}{l}\text { lateral part of mesofurca-like } \\
\text { structure }\end{array}$ \\
\hline II ism1 & $\begin{array}{l}\text { M. profurca-antecostalis } \\
\text { medialis }\end{array}$ & $\begin{array}{l}\text { lateral part of profurca-like } \\
\text { structure; mediad of II ism } 2\end{array}$ & antecosta III \\
\hline II ism2 & $\begin{array}{l}\text { M. profurca-antecostalis } \\
\text { lateralis }\end{array}$ & $\begin{array}{l}\text { lateral part of profurca-like } \\
\text { structure; laterad of II ism } 1\end{array}$ & antecosta III \\
\hline II dvm1 & $\begin{array}{l}\text { M. mesonoto-profurcalis } \\
\text { anterior }\end{array}$ & $\begin{array}{l}\text { dorsolateral part of profurca- } \\
\text { like structure; anterior to II } \\
\text { dvm2 }\end{array}$ & $\begin{array}{l}\text { mesonotum (middle of segment); } \\
\text { anterior to II dvm2 }\end{array}$ \\
\hline II dvm2 & $\begin{array}{l}\text { M. mesonoto-profurcalis } \\
\text { posterior }\end{array}$ & $\begin{array}{l}\text { dorsolateral part of profurca- } \\
\text { like structure; posterior to II } \\
\text { dvm1 }\end{array}$ & $\begin{array}{l}\text { mesonotum (middle of segment); } \\
\text { posterior to II dvm1 }\end{array}$ \\
\hline II dvm3 & $\begin{array}{l}\text { M. mesonoto-coxalis; two } \\
\text { bands }\end{array}$ & $\begin{array}{l}\text { lateral part of mesonotum } \\
\text { (middle of segment) }\end{array}$ & anterior face of mesocoxa \\
\hline II dvm4 & $\begin{array}{l}\text { M. mesonoto-subcoxalis } \\
\text { anterior; two bands }\end{array}$ & $\begin{array}{l}\text { anterolateral part of } \\
\text { mesonotum }\end{array}$ & anterior border of mesosubcoxa \\
\hline II dvm5 & $\begin{array}{l}\text { M. metanoto-subcoxalis } \\
\text { posterior }\end{array}$ & $\begin{array}{l}\text { posterolateral part of } \\
\text { mesonotum }\end{array}$ & ventral border of mesosubcoxa \\
\hline II ldvm1 & M. mesonoto-coxalis anterior & $\begin{array}{l}\text { posterolateral part of } \\
\text { mesonotum }\end{array}$ & anterior mesocoxal rim \\
\hline
\end{tabular}




\begin{tabular}{|c|c|c|c|}
\hline II ldvm2 & $\begin{array}{l}\text { M. metanoto-subcoxalis; two } \\
\text { bands }\end{array}$ & $\begin{array}{l}\text { posterolateral part of } \\
\text { mesonotum }\end{array}$ & $\begin{array}{l}\text { posteroventral border of } \\
\text { mesosubcoxa and posterior } \\
\text { border of mesocoxal rim }\end{array}$ \\
\hline II ldvm3 & M. metanoto-coxalis posterior & $\begin{array}{l}\text { posterolateral part of } \\
\text { mesonotum }\end{array}$ & anterior face of mesocoxa \\
\hline II scm 1 & M. mesofurca-coxalis 1 & $\begin{array}{l}\text { anterior face of mesofurca-like } \\
\text { structure }\end{array}$ & $\begin{array}{l}\text { posterior mesocoxal rim, laterad } \\
\text { of II scm } 2\end{array}$ \\
\hline II scm2 & M. mesofurca-coxalis 2 & $\begin{array}{l}\text { ventrolateral face of } \\
\text { mesofurca-like structure along } \\
\text { with II scm } 4\end{array}$ & $\begin{array}{l}\text { posterior mesocoxal rim, mediad } \\
\text { of II scm } 1\end{array}$ \\
\hline II scm 3 & M. mesofurca-coxalis 3 & $\begin{array}{l}\text { anterior face of mesofurca-like } \\
\text { structure }\end{array}$ & $\begin{array}{l}\text { lateral mesocoxal rim, laterad of } \\
\text { II scm } 4\end{array}$ \\
\hline II scm4 & M. mesofurca-coxalis 4 & $\begin{array}{l}\text { ventrolateral face of } \\
\text { mesofurca-like structure along } \\
\text { with II scm2 }\end{array}$ & $\begin{array}{l}\text { lateral mesocoxal rim, mediad of } \\
\text { II scm3 }\end{array}$ \\
\hline II scm5 & M. profurca-coxalis lateralis & $\begin{array}{l}\text { posterior face of profurca-like } \\
\text { structure }\end{array}$ & $\begin{array}{l}\text { anteriolateral mesocoxal rim, } \\
\text { laterad of II scm6 }\end{array}$ \\
\hline II scm6 & M. profurca-coxalis medialis & $\begin{array}{l}\text { posterior face of profurca-like } \\
\text { structure }\end{array}$ & $\begin{array}{l}\text { anteriolateral mesocoxal rim, } \\
\text { mediad of II scm5 }\end{array}$ \\
\hline III dlm 1 & $\begin{array}{l}\text { M. antecosta-antecostalis } \\
\text { medialis }\end{array}$ & antecosta 11, mediad of $111 \mathrm{dlm} 2$ & antecosta 111, mediad of $111 \mathrm{dlm} 2$ \\
\hline III d $\operatorname{lm} 2$ & $\begin{array}{l}\text { M. antecosta-antecostalis } \\
\text { lateralis }\end{array}$ & antecosta 1l, laterad of $111 \mathrm{dlm} 1$ & antecosta 111 , laterad of $111 \mathrm{dlm} 1$ \\
\hline III vlm & M. mesofurca-metafurcalis & $\begin{array}{l}\text { posterolateral face of } \\
\text { mesofurca-like structure }\end{array}$ & $\begin{array}{l}\text { anterolateral face of metafurca- } \\
\text { like structure }\end{array}$ \\
\hline III ism1 & $\begin{array}{l}\text { M. antecosta-mesofurcalis } \\
\text { anterior }\end{array}$ & $\begin{array}{l}\text { lateral face of mesofurca-like } \\
\text { structure, anteriad of } 111 \text { ism2 }\end{array}$ & antecosta 1ll, anteriad of 111 ism2 \\
\hline III ism2 & $\begin{array}{l}\text { M. antecosta-mesofurcalis } \\
\text { posterior }\end{array}$ & $\begin{array}{l}\text { lateral face of mesofurca-like } \\
\text { structure, posteriad of III ism1 }\end{array}$ & antecosta 11l, posteriad of 111 ism 1 \\
\hline III dvm1 & $\begin{array}{l}\text { M. metanoto-mesofurcalis } \\
\text { anterior }\end{array}$ & $\begin{array}{l}\text { lateral face of mesofurca-like } \\
\text { structure, anteriad of } 111 \mathrm{dvm} 2\end{array}$ & $\begin{array}{l}\text { lateral part metanotum (middle of } \\
\text { segment), anteriad of } 111 \mathrm{dvm} 2\end{array}$ \\
\hline III dvm2 & $\begin{array}{l}\text { M. metanoto-mesofurcalis } \\
\text { posterior }\end{array}$ & $\begin{array}{l}\text { lateral face of mesofurca-like } \\
\text { structure, posteriad of } 111 \mathrm{dvm} 1\end{array}$ & $\begin{array}{l}\text { lateral part of metanotum (middle } \\
\text { of segment), posteriad of } 111 \mathrm{dvm} 1\end{array}$ \\
\hline III dvm3 & $\begin{array}{l}\text { M. metanoto-coxalis; two } \\
\text { bands }\end{array}$ & anterolateral part of metanotum & anterior metacoxal rim \\
\hline III dvm4 & $\begin{array}{l}\text { M. metanoto-subcoxalis } \\
\text { anterior; two bands }\end{array}$ & anterolateral part of metanotum & anterior border of metasubcoxa \\
\hline III dvm5 & $\begin{array}{l}\text { M. metanoto-subcoxalis } \\
\text { posterior }\end{array}$ & $\begin{array}{l}\text { posterolateral part of } \\
\text { metanotum }\end{array}$ & ventral border of metasubcoxa \\
\hline III ldvm1 & M. metanoto-coxalis anterior & $\begin{array}{l}\text { lateral part of metanotum } \\
\text { (middle of segment) }\end{array}$ & anterior metacoxal rim \\
\hline III ldvm3 & M. metanoto-coxalis posterior & $\begin{array}{l}\text { lateral part of metanotum } \\
\text { (middle of segment) }\end{array}$ & anterior face of metacoxa \\
\hline III ldvm2 & $\begin{array}{l}\text { M. metanoto-subcoxalis; two } \\
\text { bands }\end{array}$ & $\begin{array}{l}\text { lateral part of metanotum } \\
\text { (middle of segment) }\end{array}$ & $\begin{array}{l}\text { posteroventral border of } \\
\text { metasubcoxa }\end{array}$ \\
\hline III scm 1 & M. metafurca-coxalis 1 & $\begin{array}{l}\text { ventromedial face of } \\
\text { metafurca-like structure }\end{array}$ & posterior metacoxal rim \\
\hline III scm2 & M. metafurca-coxalis 2 & $\begin{array}{l}\text { ventrolateral face of } \\
\text { metafurca-like structure }\end{array}$ & lateral metacoxal rim \\
\hline III scm3 & M. metafurca-coxalis 3 & $\begin{array}{l}\text { lateral face of metafurca-like } \\
\text { structure }\end{array}$ & lateral metacoxal rim \\
\hline III scm5 & M. mesofurca-coxalis lateralis & $\begin{array}{l}\text { posterior face of mesofurca- } \\
\text { like structure }\end{array}$ & $\begin{array}{l}\text { anteriolateral metacoxal rim, } \\
\text { laterad of III scm6 }\end{array}$ \\
\hline III scm6 & M. mesofurca-coxalis medialis & $\begin{array}{l}\text { posterior face of mesofurca- } \\
\text { like structure }\end{array}$ & $\begin{array}{l}\text { anteriolateral metacoxal rim, } \\
\text { mediad of III scm5 }\end{array}$ \\
\hline
\end{tabular}


Table 3 (on next page)

Abdominal muscle origins and insertions. 


\begin{tabular}{|c|c|c|c|}
\hline Abbrev. & Name & Origin & Insertion \\
\hline AI dlm1 & $\begin{array}{l}\text { M. antecosta-antecostalis } \\
\text { medialis }\end{array}$ & antecosta III, mediad of AI dlm2 & $\begin{array}{l}\text { antecosta IV, mediad of AI } \\
\text { dlm2 }\end{array}$ \\
\hline AI d $\operatorname{lm} 2$ & $\begin{array}{l}\text { M. antecosta-antecostalis } \\
\text { lateralis }\end{array}$ & antecosta III, laterad of AI dlm1 & $\begin{array}{l}\text { antecosta IV, laterad of AI } \\
\text { dlm1 }\end{array}$ \\
\hline AI vlm & $\begin{array}{l}\text { M. metafurca- } \\
\text { endosternalis }\end{array}$ & $\begin{array}{l}\text { lateral face of metafurca-like } \\
\text { structure }\end{array}$ & endosternite \\
\hline AI ism1 & $\begin{array}{l}\text { M. antecosta- } \\
\text { metafurcalis anterior }\end{array}$ & antecosta IV, anteriad of AI ism2 & $\begin{array}{l}\text { lateral face of metafurca-like } \\
\text { structure, anteriad of AI ism2 }\end{array}$ \\
\hline AI ism2 & $\begin{array}{l}\text { M. antecosta- } \\
\text { metafurcalis posterior }\end{array}$ & antecosta IV, posteriad of AI ism 1 & $\begin{array}{l}\text { lateral face of metafurca-like } \\
\text { structure, posteriad of AI ism1 }\end{array}$ \\
\hline AI dvm1 & $\begin{array}{l}\text { M. tergo-metafurcalis } \\
\text { anterior }\end{array}$ & $\begin{array}{l}\text { middle region region of tergum, } \\
\text { anteriad of AI dvm2 }\end{array}$ & $\begin{array}{l}\text { lateral face of metafurca-like } \\
\text { structure, anteriad of AI dvm2 }\end{array}$ \\
\hline AI dvm2 & $\begin{array}{l}\text { M. tergo-metafurcalis } \\
\text { posterior }\end{array}$ & $\begin{array}{l}\text { middle region region of tergum, } \\
\text { posteriad of AI dvm1 }\end{array}$ & $\begin{array}{l}\text { lateral face of metafurca-like } \\
\text { structure, posteriad of AI dvm } 1\end{array}$ \\
\hline AI dvm3 & M. pleuro-pleuralis & lateral wall of segment & tendon system \\
\hline AI dvm4 & M. tergo-pleuralis & posterior region of tergum & tendon system \\
\hline AI ldvm1 & M. pleuro-metafurcalis & lateral wall of segment & $\begin{array}{l}\text { lateral face of metafurca-like } \\
\text { structure }\end{array}$ \\
\hline AI dvm VT & M. tergo-pleuralis & anterior region of tergum & tendon system \\
\hline AI $\operatorname{lm}$ & $\begin{array}{l}\text { M. ventratubularis } \\
\text { lateralis } 1\end{array}$ & base of ventral tube & valva of ventral tube \\
\hline AI pm1 & $\begin{array}{l}\text { M. sterno-coxalis } \\
\text { proximalis anterior } 1\end{array}$ & base of ventral tube & metafurca-like structure \\
\hline AI pm2 & $\begin{array}{l}\text { M. sterno-coxalis } \\
\text { proximalis anterior } 2\end{array}$ & $\begin{array}{l}\text { base of ventral tube, anteriad of AI } \\
\text { pm3, ventrad of AI pm4 }\end{array}$ & tendon system \\
\hline AI pm3 & $\begin{array}{l}\text { M. sterno-coxalis } \\
\text { proximalis anterior } 3\end{array}$ & $\begin{array}{l}\text { base of ventral tube, posteriad of AI } \\
\text { pm2, AI pm4 }\end{array}$ & tendon system \\
\hline AI pm4 & $\begin{array}{l}\text { M. coxalis proximalis } \\
\text { posterior } 1\end{array}$ & $\begin{array}{l}\text { base of ventral tube, anteriad of AI } \\
\text { pm3, dorsad of AI pm2 }\end{array}$ & tendon system \\
\hline $\mathrm{AI} \mathrm{dm} 1$ & M. sterno-vesicularis & $\begin{array}{l}\text { anterior face of ventral tube, laterad } \\
\text { of AI dm3 }\end{array}$ & metafurca-like structure \\
\hline AI dm2 & $\begin{array}{l}\text { M. tergo-vesicularis } \\
\text { anterior }\end{array}$ & $\begin{array}{l}\text { vesicles of ventral tube, ventrad of } \\
\text { AI dm4 }\end{array}$ & endosternite \\
\hline AI dm3 & M. coxo-vesicularis & $\begin{array}{l}\text { anterior face of ventral tube, } \\
\text { mediad of AI dm1 }\end{array}$ & metafurca-like structure \\
\hline $\mathrm{AI} \mathrm{dm} 4$ & $\begin{array}{l}\text { M. tergo-vesicularis } \\
\text { posterior }\end{array}$ & $\begin{array}{l}\text { vesicles of ventral tube, laterad of } \\
\text { AI dm2 }\end{array}$ & endosternite \\
\hline AI dm5 & $\begin{array}{l}\text { M. coxo-vesicularis } \\
\text { anterior }\end{array}$ & posterior face of ventral tube & tendon system \\
\hline AII d $\operatorname{lm} 1$ & $\begin{array}{l}\text { M. antecosta-antecostalis } \\
\text { medialis }\end{array}$ & antecosta IV, mediad of AII dlm2 & $\begin{array}{l}\text { antecosta } \mathrm{V}, \text { mediad of AII } \\
\text { d lm2 }\end{array}$ \\
\hline AII d $\operatorname{lm} 2$ & $\begin{array}{l}\text { M. antecosta-antecostalis } \\
\text { lateralis }\end{array}$ & antecosta $1 \mathrm{~V}$, laterad of AII dlm1 & $\begin{array}{l}\text { antecosta V, laterad of AII } \\
\text { dlm1 }\end{array}$ \\
\hline AII vlm & $\begin{array}{l}\text { M. endosterno- } \\
\text { antecostalis }\end{array}$ & endosternite & antecosta $\mathrm{V}$ \\
\hline AII ism1 & $\begin{array}{l}\text { M. antecosta- } \\
\text { endosternalis anterior }\end{array}$ & antecosta $\mathrm{V}$, anteriad of AII ism 2 & $\begin{array}{l}\text { endosternite, anteriad of AII } \\
\text { ism } 2\end{array}$ \\
\hline AII ism2 & $\begin{array}{l}\text { M. antecosta- } \\
\text { endosternalis posterior }\end{array}$ & antecosta $\mathrm{V}$, posteriad of AII ism 1 & $\begin{array}{l}\text { endosternite, posteriad of AII } \\
\text { ism } 1\end{array}$ \\
\hline AII dvm1 & $\begin{array}{l}\text { M. tergo-endosternalis } \\
\text { anterior }\end{array}$ & $\begin{array}{l}\text { middle region of tergum, anteriad } \\
\text { of AII dvm2 }\end{array}$ & $\begin{array}{l}\text { endosternite, anteriad of AII } \\
\text { dvm2 }\end{array}$ \\
\hline
\end{tabular}




\begin{tabular}{|c|c|c|c|}
\hline AII dvm2 & $\begin{array}{l}\text { M. tergo-endosternalis } \\
\text { posterior }\end{array}$ & $\begin{array}{l}\text { middle region of tergum, posteriad } \\
\text { of AII dvm } 1\end{array}$ & $\begin{array}{l}\text { endosternite, posteriad of AII } \\
\text { dvm1 }\end{array}$ \\
\hline AII ldvm1 & M. tergo-sternalis & lateral wall of segment & sternum \\
\hline AII dvm3 & $\begin{array}{l}\text { M. tergo-sternalis } \\
\text { anterior }\end{array}$ & $\begin{array}{l}\text { anterior border of tergum, anteriad } \\
\text { of AII dvm } 4\end{array}$ & $\begin{array}{l}\text { lateral border of sternum, } \\
\text { anteriad of AII dvm } 4\end{array}$ \\
\hline AII dvm4 & $\begin{array}{l}\text { M. tergo-sternalis } \\
\text { posterior }\end{array}$ & $\begin{array}{l}\text { lateral area of tergum, posteriad of } \\
\text { AII dvm3 }\end{array}$ & $\begin{array}{l}\text { lateral border of sternum, } \\
\text { posteriad of AII dvm3 }\end{array}$ \\
\hline AII trm1 & $\begin{array}{l}\text { M. endosterno- } \\
\text { endosternalis }\end{array}$ & inner surface of endosternite & $\begin{array}{l}\text { inner surface of endosternite } \\
\text { (opposite side) }\end{array}$ \\
\hline AIII dlm 1 & $\begin{array}{l}\text { M. antecosta-antecostalis } \\
\text { medialis }\end{array}$ & antecosta $\mathrm{V}$, mediad of AIII dlm2 & $\begin{array}{l}\text { antecosta Vl, mediad of AIII } \\
\text { dlm2 }\end{array}$ \\
\hline AIII d $\operatorname{lm} 2$ & $\begin{array}{l}\text { M. antecosta-antecostalis } \\
\text { lateralis }\end{array}$ & antecosta $\mathrm{V}$, laterad of AIII dlm1 & $\begin{array}{l}\text { antecosta Vl, laterad of AIII } \\
\text { dlm1 }\end{array}$ \\
\hline AIII ism1 & $\begin{array}{l}\text { M. antecosta-antecostalis } \\
\text { medialis }\end{array}$ & antecosta VI, mediad of AIII ism2 & $\begin{array}{l}\text { ventral area of antecosta } \mathrm{V}, \\
\text { mediad of AIII ism2 }\end{array}$ \\
\hline AIII ism2 & $\begin{array}{l}\text { M. antecosta-antecostalis } \\
\text { lateralis }\end{array}$ & antecosta VI, laterad of AIII ism1 & $\begin{array}{l}\text { ventral area of antecosta V, } \\
\text { laterad of AIII ism1 }\end{array}$ \\
\hline AIII dvm1 & $\begin{array}{l}\text { M. tergo-antecostalis } \\
\text { anterior }\end{array}$ & $\begin{array}{l}\text { middle region of tergum, anteriad } \\
\text { of AIII dvm } 2\end{array}$ & $\begin{array}{l}\text { ventral area of antecosta } \mathrm{V}, \\
\text { anteriad of AIII dvm2 }\end{array}$ \\
\hline AIII dvm2 & $\begin{array}{l}\text { M. tergo-antecostalis } \\
\text { posterior }\end{array}$ & $\begin{array}{l}\text { middle region of tergum, posteriad } \\
\text { of AIII dvm1 }\end{array}$ & $\begin{array}{l}\text { ventral area of antecosta } \mathrm{V}, \\
\text { posteriad of AIII dvm1 }\end{array}$ \\
\hline AIII dvm3 & $\begin{array}{l}\text { M. tergo-sternalis } \\
\text { anterior }\end{array}$ & $\begin{array}{l}\text { anterior border of tergum, anteriad } \\
\text { of AIII dvm } 4\end{array}$ & $\begin{array}{l}\text { lateral border of sternum, } \\
\text { anteriad of AIII dvm4 }\end{array}$ \\
\hline AIII dvm4 & $\begin{array}{l}\text { M. tergo-sternalis } \\
\text { posterior }\end{array}$ & $\begin{array}{l}\text { lateral area of tergum, posteriad of } \\
\text { AIII dvm3 }\end{array}$ & $\begin{array}{l}\text { lateral border of sternum, } \\
\text { posteriad of AIII dvm3 }\end{array}$ \\
\hline AIII ldvm1 & M. tergo-sternalis & lateral wall of segment & sternum \\
\hline AIV d $\operatorname{lm} 1$ & $\begin{array}{l}\text { M. antecosta-antecostalis } \\
\text { medialis }\end{array}$ & antecosta Vl, mediad of AlV dlm2 & $\begin{array}{l}\text { antecosta VII, mediad of AlV } \\
\text { dlm2 }\end{array}$ \\
\hline AIV d $\operatorname{lm} 2$ & $\begin{array}{l}\text { M. antecosta-antecostalis } \\
\text { lateralis }\end{array}$ & antecosta Vl, laterad of AlV dlm1 & $\begin{array}{l}\text { antecosta VII, laterad of AIV } \\
\text { dlm1 }\end{array}$ \\
\hline AlV vlm & M. antecosta-antecostalis & antecosta $\mathrm{V}$ & antecosta VII \\
\hline AIV ism1 & M. antecosta-antecostalis & dorsal part of antecosta VI & ventral part of antecosta VII \\
\hline AIV dvm1 & $\begin{array}{l}\text { M. tergo-sternalis } \\
\text { posterior }\end{array}$ & $\begin{array}{l}\text { anterior border of tergum, posteriad } \\
\text { of AIV dvm3 }\end{array}$ & $\begin{array}{l}\text { posterior border of sternum, } \\
\text { posteriad of AIV dvm3 }\end{array}$ \\
\hline AIV dvm2 & M. tergo-sternalis 1 & lateral wall of segment & sternum,along with AIV ldvm5 \\
\hline AIV dvm3 & $\begin{array}{l}\text { M. tergo-sternalis } \\
\text { anterior }\end{array}$ & $\begin{array}{l}\text { anterior border of tergum, anteriad } \\
\text { of AIV dvm } 1\end{array}$ & $\begin{array}{l}\text { lateral board of sternum, } \\
\text { anteriad of AIV dvm1 }\end{array}$ \\
\hline AIV ldvm3 & M. tergo-antecostalis & posterior region of tergum & ventral part of antecosta VII \\
\hline AIV ldvm4 & M. tergo-sternalis 2 & posterior region of tergum & lateral board of sternum \\
\hline AIV ldvm5 & M. tergo-sternalis 3 & posterior region of tergum & sternum, along with AIV dvm2 \\
\hline AIV ldvm7 & M. tergo-sternalis 4 & lateral wall of segment & lateral board of sternum \\
\hline AV d $\operatorname{lm} 1$ & $\begin{array}{l}\text { M. antecosta-antecostalis } \\
\text { medialis }\end{array}$ & antecosta VII, mediad of AV dlm2 & $\begin{array}{l}\text { antecosta VIII, mediad of AV } \\
\text { dlm2 }\end{array}$ \\
\hline AV d $\operatorname{lm} 2$ & $\begin{array}{l}\text { M. antecosta-antecostalis } \\
\text { lateralis }\end{array}$ & antecosta VII, laterad of AV dlm1 & $\begin{array}{l}\text { antecosta VIII, laterad of AV } \\
\text { dlm1 }\end{array}$ \\
\hline $\mathrm{AV}$ ism1 & $\begin{array}{l}\text { M. tergo- } \\
\text { intersegmentalis }\end{array}$ & anterior region of tergum & $\begin{array}{l}\text { intersegmental area between } \\
5 \text { th and 6th segments }\end{array}$ \\
\hline AV ldvm1 & M. tergo-sternalis & lateral wall of segment & sternum \\
\hline AVl sm1 & M. sterno-rectalis 1 & posteriolateral board of sternum & rectum, posteriad of AVI sm1 \\
\hline AVI sm2 & M. sterno-rectalis 2 & lateral board of sternum & rectum, anteriad of AVI sm2 \\
\hline AVl dvm1 & M. tergo-rectalis & anterior region of tergum & rectum, anteriad of AVI dvm2 \\
\hline AVI dvm2 & M. tergo-sternalis 1 & central region of tergum & rectum, posteriad of AVI dvm1 \\
\hline AVI dvm3 & M. tergo-sternalis 2 & posterior region of tergum & dorsal anal lobe \\
\hline AVl dvm4 & M. tergo-sternalis 3 & lateral wall of segment & lateral anal lobe \\
\hline
\end{tabular}

